\title{
DETERMINANTS OF CAPITAL STRUCTURE IN CANADIAN NON-FINANCIAL
}

\section{FIRMS: A RECENT STUDY}

\author{
by \\ Krisha Amatya \\ BBA (Global Business Management), \\ Sheridan College, \\ Ontario, Canada, 2015

\begin{abstract}
A thesis
presented to Ryerson University

in partial fulfillment of the

requirements for the degree of

in the program of
\end{abstract} \\ Master of Science in Management \\ Master of Science in Management
}

Toronto, Ontario, Canada, 2020

CKrisha Amatya, 2020 


\section{AUTHOR'S DECLARATION FOR ELECTRONIC SUBMISSION OF A THESIS}

I hereby declare that I am the sole author of this thesis. This is a true copy of the thesis, including any required final revisions, as accepted by my examiners.

I authorize Ryerson University to lend this thesis to other institutions or individuals for the purpose of scholarly research.

I further authorize Ryerson University to reproduce this thesis by photocopying or by other means, in total or in part, at the request of other institutions or individuals for the purpose of scholarly research.

I understand that my thesis may be made electronically available to the public. 
DETERMINANTS OF CAPITAL STRUCTURE IN CANADIAN NON-FINANCIAL FIRMS:

\title{
A RECENT STUDY
}

Krisha Amatya

Master of Science in Management

Ryerson University

Toronto, Ontario, Canada, 2020

\begin{abstract}
The purpose of this research is to examine firm-specific determinants of capital structure in Canadian non-financial firms. The research uses a sample of 208 firms listed on Toronto Stock Exchange from 1999 to 2016. Panel data analysis has been performed using a fixed effects model estimation. The study also investigates the impact of firm-specific factors on capital structure in three different phases: pre-crisis (1999-2006), during crisis (2007-2009), and post-crisis (2010-2016).
\end{abstract}

The analysis suggests that age, liquidity, asset tangibility, size, growth opportunities, and profitability are the determinants of capital structure in Canadian non-financial firms. The findings suggest that Pecking Order Theory better explains capital structure choices across Canadian non-financial firms. However, some hypotheses of Trade-off Theory are also applicable in certain contexts. This study adds to the existing literature on factors influencing capital structure of Canadian non-financial firms. Both practitioners and academicians may benefit from the findings of this study. 


\section{ACKNOWLEDGEMENTS}

I would like to express my sincere gratitude to my supervisor, Professor Dr. Ayse Yuce,

for her guidance, encouragement, and advice throughout my journey as a graduate student. I find myself incredibly fortunate to have completed this thesis under her supervision.

I would like to acknowledge the committee members, Associate Professor Dr. Sergiy Rakhmayil and Assistant Professor Dr. Laleh Samarbakhsh, who reviewed my thesis and provided me with their insightful comments.

I am extremely grateful to my parents who have always supported and encouraged me in achieving my educational goals. 


\section{Table of Contents}

AUTHOR'S DECLARATION FOR ELECTRONIC SUBMISSION OF A THESIS...........................ii

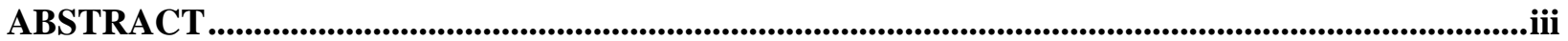

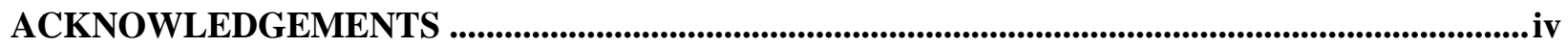

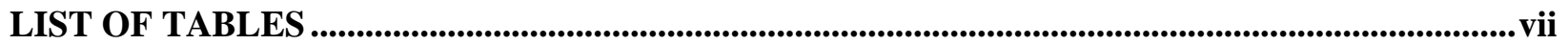

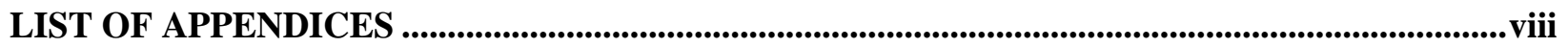

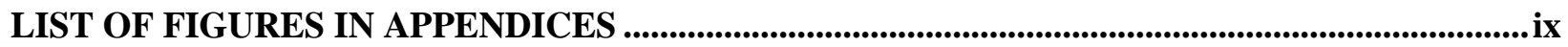

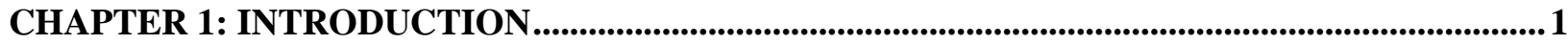

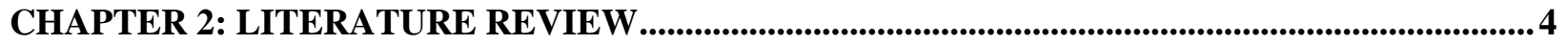

2.1 M\&M Theory and Optimal Capital Structure ....................................................... 4

2.2 Evolution of Alternative Theories and Concepts .................................................. 5

2.3 International Research on Capital Structure ....................................................... 8

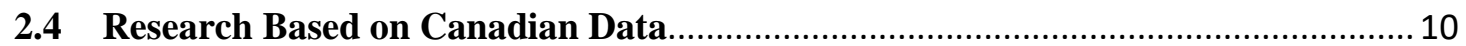

2.5 Trade-off Theory and Pecking Order Theory of Capital Structure ........................ 12

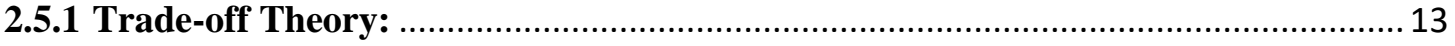

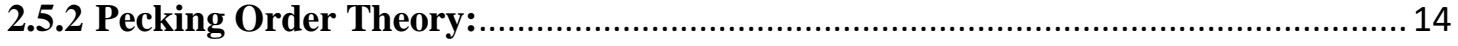

2.6 Theoretical Propositions of Trade-off Theory and Pecking Order Theory ….......... 15

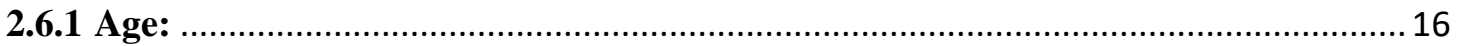

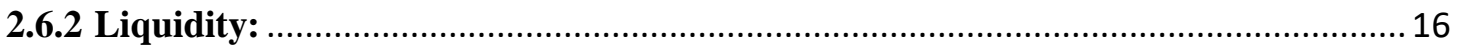

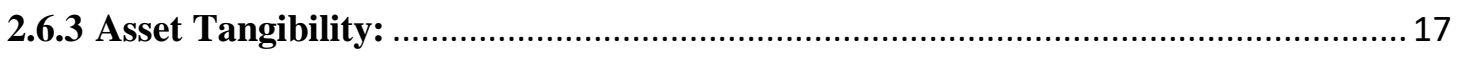

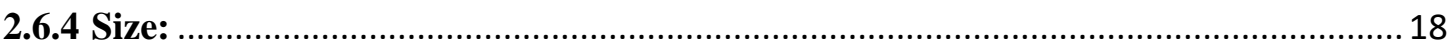

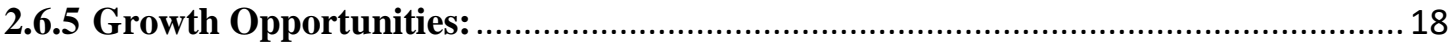

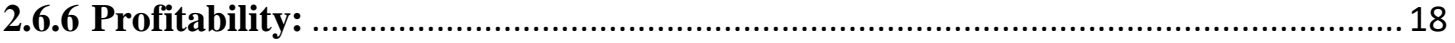

2.6.7 Non-Debt Tax Shields (NDTS): ........................................................................ 19

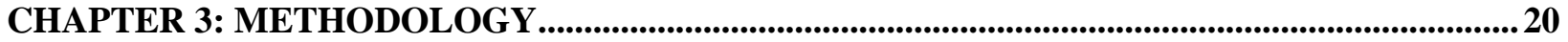

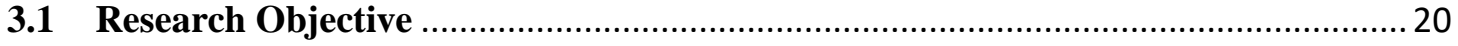

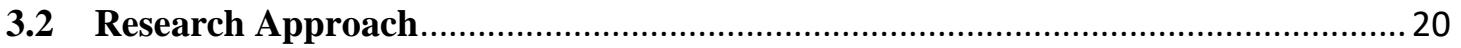

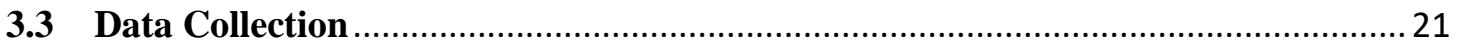

3.4 Firm-Specific Factors Affecting Capital Structure (Debt Ratio) ........................... 22

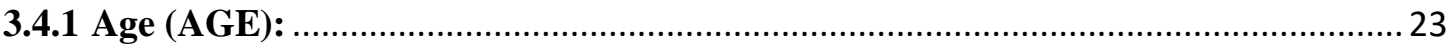

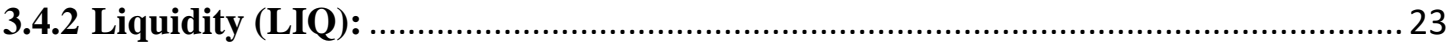

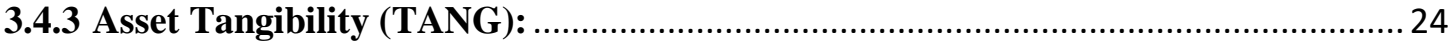




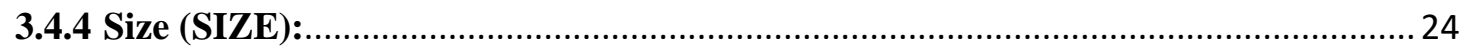

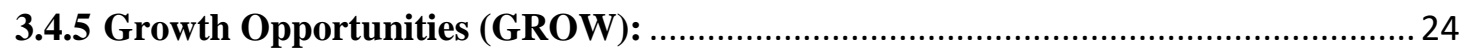

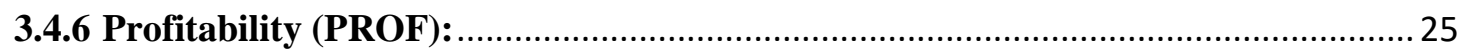

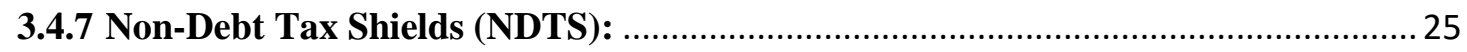

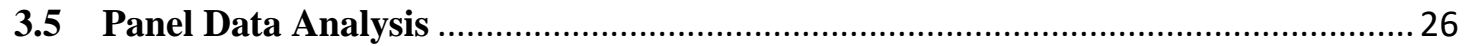

3.5.1 One-Way Error Component Regression: ........................................................... 27

3.5.2 Test Models for Two-Way Error Component Regression: ................................... 27

3.5.3 Test Models for Fixed Effects Dummy Variable Regression: ................................... 28

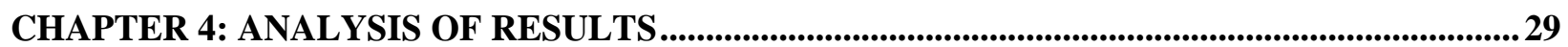

CHAPTER 5: FINDINGS AND CONCLUSIONS .......................................................................4 41

CHAPTER 6: LIMITATIONS AND SCOPE OF FUTURE RESEARCH ............................................44

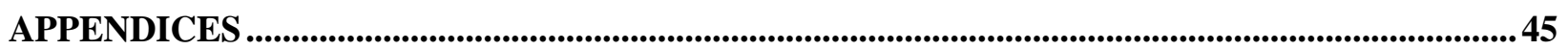

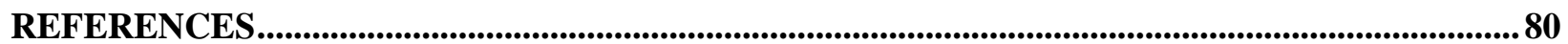




\section{LIST OF TABLES}

Table 1: Theoretical propositions of Trade-off Theory and Pecking Order Theory ........... 16

Table 2: Industry classifications of the companies in sample data ...................................... 22

Table 3: Probability tests for one-way fixed effects model and one-way random effects

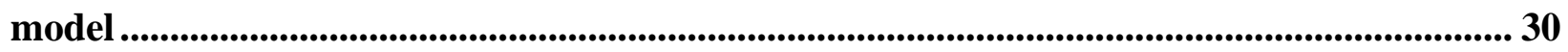

Table 4: Parameter estimates of one-way fixed effects model from 1999 to 2016 ................ 31

Table 5: Parameter estimates of one-way fixed effects model from 1999 to 2006 ................ 32

Table 6: Parameter estimates of one-way fixed effects model from 2007 to 2009 ................. 33

Table 7: Parameter estimates of one-way fixed effects model from 2010 to 2016 ................ 34

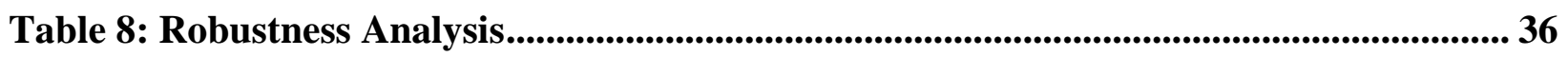

Table 9: Difference in parameter estimates of fixed effects models (one-way and two-way)

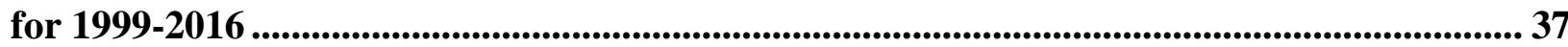

Table 10: Difference in parameter estimates of fixed effects models (one-way and two-way)

for $2007-2009$.................................................................................................................................. 37

Table 11: Difference in parameter estimates of fixed effects models (one-way, one-time, and two-way) with Industry Dummy Variables for 1999 to 2016............................................... 39

Table 12: Difference in parameter estimates of fixed effects models (one-way, one-time, and two-way) with Industry Dummy Variables for 2007 to 2009................................................... 40 


\section{LIST OF APPENDICES}

Appendix A: List of Companies from Research Data .................................................................. 46

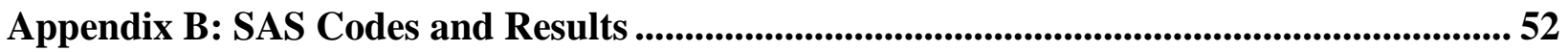

Appendix C: Robustness Test - Grouping of Companies and Results ................................... 73 


\section{LIST OF FIGURES IN APPENDICES}

Figure 2: Results of one-way fixed effects model for 1999 to 2016 ........................................... 55

Figure 3: Results of one-way fixed effects model for 1999 to 2006 ...................................... 56

Figure 4: Results of one-way fixed effects model for 2007 to 2009.................................... 57

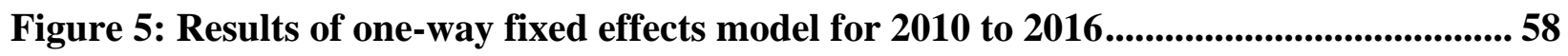

Figure 6: Hausman test results of one-way random effects model for 1999 to 2016 ............ 59

Figure 7: Hausman test results of one-way random effects model for 1999 to 2006 ............ 60

Figure 8: Hausman test results of one-way random effects model for 2007 to 2009 ............ 61

Figure 9: Hausman test results of one-way random effects model for 2010 to 2016 ............ 62

Figure 10: Hausman test results (with Industry Dummy Variables) of one-way random

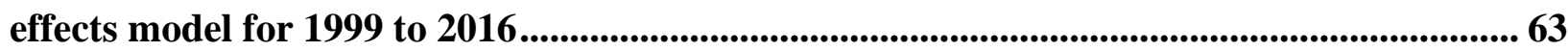

Figure 11: Hausman test results (with Industry Dummy Variables) of one-way random

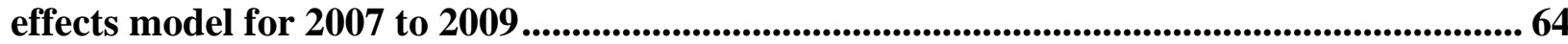

Figure 12: Hausman test results of two-way random effects model for 1999 to 2016 ........... 65

Figure 13: Hausman test results of two-way random effects model for 2007 to 2009 ........... 66

Figure 14: Hausman test results (with Industry Dummy Variables) of two-way random effects model for 1999 to 2016.

Figure 15: Hausman test results (with Industry Dummy Variables) of two-way random effects model for 2007 to 2009. 68

Figure 16: Results of fixed effects models (one-way, one-time, and two-way) for 1999 to 2016.

Figure 17: Results of fixed effects models (one-way, one-time, and two-way) with Industry

Dummy Variables for 1999 to 2016 70

Figure 18: Results of fixed effects models (one-way, one-time, and two-way) for 2007 to 2009. 71

Figure 19: Results of fixed effects models (one-way, one-time, and two-way) with Industry Dummy Variables for 2007 to 2009 72

Figure 20: Robustness test results after excluding Group 2 companies - one-way fixed effects model for 1999 to 2016 . 79 


\section{CHAPTER 1: INTRODUCTION}

Financial resources play an important role in a firm's success because it is one of the key factors that drive firms' operations and growth. Managers spend a significant amount of time and effort in choosing between debt and equity (or the best possible combination of both) to finance their firms' operations and growth. It is known as "capital structure decision". There are costs and benefits associated with each financing option. Therefore, capital structure decision is crucial for survival of a firm (Danso \& Adomako, 2010).

Capital structure has been one of the most argumentative issues in the area of finance since the late 1950s (Bradley, Jarrell, \& Kim, 1984). After Modigliani and Miller proposed the concept of optimal capital structure in 1958 (revised in 1963) and provided foundation for Tradeoff Theory, several theories were introduced to explain capital structure choices across firms. Agency Theory (introduced by Jensen and Meckling in 1976) and Pecking Order Theory (introduced by Donaldson in 1961 and reintroduced by Myers and Majluf in 1984) added new dimensions in capital structure theory by introducing agency cost and information asymmetry cost associated with issuance of shares, respectively.

Empirical works in the area of capital structure have not come up with a universal model because each model has a set of concepts and relationships that are completely different from others (Titman \& Wessels, 1988; Myers, 2001). It is difficult to reject any theoretical framework based on available evidence. Therefore, empirical works should be aimed particularly at figuring out determinants of capital structure in various contexts (Harris \& Raviv, 1991). Empirical works on capital structure must formulate and test the hypotheses that can be rejected. This is regarded as a challenge to both theoretical and empirical research (Shyam-Sunder \& Myers, 1999). 
As per the traditional concept, firms strive to minimize Weighted Average Cost of Capital (WACC) by choosing the least expensive financing option. Borrowing debt is supposedly cheaper than issuing shares. Therefore, firms try to achieve an optimal capital structure (minimize WACC) by adding more debt to their capital structure. Beyond the optimal point, WACC begins to rise because excess debt financing creates unnecessary devaluation of the firm and puts it at a higher risk of bankruptcy (Ross, Westerfield, Jordan, \& Roberts, 2016).

The term "capital structure" is commonly used as a synonym of corporate debt or firm leverage. Many researchers have found a relationship between firm-specific factors and firm leverage. Bhaduri (2002) stated that capital structure is determined by a firm's operating cash flow, growth opportunities, size, restructuring costs, products, and industry characteristics. Mishra (2011) suggested that firm leverage is affected by profitability, asset structure and effective tax rate. Adhegaonkar and Indi (2012) found asset tangibility, Non-Debt Tax Shields (NDTS) and Interest Coverage Ratio (ICR) to be significant determinants of capital structure. Majumdar (2012) argued that asset tangibility, growth opportunities, profitability and firmspecific risk are significant determinants of capital structure. Mukherjee and Mahakud (2010) stated that market-to-book ratio, size, profitability, and asset tangibility are significant determinants of firm leverage. Sinha and Ghosh (2010) claimed that growth opportunities, size and profitability are the significant determinants of capital structure. Rajagopal (2009) stated that fixed asset ratio, size, profitability, market-to-book ratio, NDTS and earnings volatility are determinants of capital structure. Purohit and Khanna (2012) concluded that growth opportunities, collateral value of assets and Research and Development (R\&D) expenditures are significant determinants of capital structure. Lim (2012) claimed that profitability, size, NDTS, earnings volatility and non-circulating shares are significant determinants of capital structure. 
Cortez and Susanto (2012) claimed that asset tangibility, profitability and NDTS are the significant determinants of capital structure. Kouki and Said (2012) empirically proved that size, profitability, growth opportunities, and NDTS are the significant determinants of capital structure (as cited in Chadha \& Sharma, 2015).

Canada is one of the G-7 countries with stable GDP structure. Canadian economy seemed more stable compared to the U.S. economy during the financial crisis of 2007 to 2009 (Hossain \& Nguyen, 2016b). Canada is different from other countries on several aspects, such as culture, institutions, and operating environment of firms. Thus, what is relevant to other countries may not be relevant to Canada (Nunkoo \& Boateng, 2010).

Publicly traded Canadian non-financial firms significantly depend on corporate debt and bonds. Therefore, it is essential to understand the effects of firm-specific factors in determining capital structure of non-financial firms in Canada. This study adds to the existing knowledge on capital structure in Canada, since the study covers pre-crisis (1999-2006), during crisis (20072009), and post-crisis (2010-2016) investigations of capital structure determinants across Canadian non-financial firms.

The remainder of this research paper is organized as follows: The second chapter provides the review of literature and theories on capital structure decisions of firms; the third chapter discusses research methodology; the fourth chapter analyses the results, the fifth chapter provides findings and concluding remarks, and the sixth chapter discusses limitations and scope of future research. 


\section{CHAPTER 2: LITERATURE REVIEW}

\subsection{M\&M Theory and Optimal Capital Structure}

The noble prize-winning professors, Modigliani and Miller or M\&M (1958), were the first scholars to start debate on the relevance of capital structure on a firm's value. They argued that in a perfect capital market without taxes, transaction costs, and information asymmetry, a firm's value is unaffected by its capital structure. According to this concept, whether a firm uses debt or equity as a financing option, it should have no material effect on a firm's value. Therefore, firms can use any proportion of debt and equity in their capital structure, as any combination is just as good as the others, and could be considered as an optimal capital structure (Modigliani \& Miller, 1958). Their theory is based on following assumptions: capital market is efficient and there is no communication gap between internal and external stakeholders; there are no transaction costs or bankruptcy costs; and choosing between debt and equity financing is a needless effort. This model served as a starting point for presenting more realistic concepts that explain why debt is preferred over equity (Chen \& Strange, 2005).

In 1963, Modigliani and Miller revised their theory of "optimal capital structure" and added the role of tax advantage in determining capital structure. According to the revised theory, firms use debt to take advantage of tax shields, to reduce cost of capital, and to subsequently maximize firms' value. They further added that transaction costs associated with debt should be equivalent to the tax-benefits from debt financing. Therefore, even in the imperfect capital market with taxes and transaction costs, capital structure choice has no effect on firms' market value (Modigliani \& Miller, 1963). 
After Modigliani and Miller (1963), Kraus and Litzenberger (1973) took the concept of "optimal capital structure" further and explained the possibility of trade-off between tax-benefits of debt and the cost of financial distress associated with debt. An optimal debt ratio (optimal capital structure) can therefore be attained by creating a reasonable balance between the tax-free benefit of debt and the distress cost associated with debt (Kraus \& Litzenberger, 1973). The concept of optimal capital structure later developed into "Trade-off Theory".

Jensen and Meckling (1976) explained "Trade-off Theory" from an agency cost perspective. Agency cost is the cost to control and monitor activities of managers so that they act in best interest of shareholders, and there is no conflict between managers and shareholders. This perspective is also known as "Agency Theory". As per the theory, optimal debt ratio (optimal capital structure) minimizes agency costs. When a firm borrows debt, managers have a responsibility to ensure efficient functioning of business activities so that interest obligations are met (M. Jensen \& Meckling, 1976).

\subsection{Evolution of Alternative Theories and Concepts}

Miller (1977) proposed a concept of debt and taxes, which is an extension of Modigliani and Miller Proposition II (1963). In his analysis, he mentioned three different taxes: corporate tax rate, personal tax rate applicable to common stock gains, and personal tax rate applicable to interest income from bonds. Personal tax rate applies to interest income from bonds, but corporations can deduct the "interest paid to bondholders" from their taxable income. Personal tax rate applies to common stock gains as well, but it may be exempted in special cases. Additionally, if personal tax rate on income bonds is greater than personal tax rate on common stocks, the bondholders will have no interest to make investments, although corporations may 
want to use more debt instead of equity due to tax advantages. In this case, bondholders will demand higher before-tax return on their investments, other things equal, to offset the tax disadvantage. The equilibrium point is where the net effect of all taxes is zero, and that is the point at which optimum debt ratio is created (Miller, 1977).

DeAngelo and Masulis (1980) introduced a concept of Non-Debt Tax Shields (NDTS), and stated that there are alternatives to debt-related tax shields, such as depreciation, investment tax credits, tax loss carried forward, etc. The tax shields on interest payments may look attractive, but it decreases earnings and make it insufficient to offset taxes. Therefore, firms with higher NDTS are likely to use less debt in their capital structure (DeAngelo \& Masulis, 1980). This indicates that non-debt tax shields can substitute tax shields on debt, which is why the relationship between NDTS and leverage should be negative (DeAngelo \& Masulis, 1980; as cited in Sheikh \& Wang, 2011).

Myers and Majluf (1984) redefined Pecking Order Theory, which was initially proposed by Donaldson (1961) in his book “A Study of Corporate Debt Policy and the Determination of Corporate Debt Capacity". The theory is based on notion of information asymmetry between shareholders, managers, and creditors (also referred as debtholders or bondholders), when raising capital. Pecking Order Theory rejects the existence of an optimal debt ratio and argues that firms usually follow a hierarchy of corporate finance in choosing a financing option; that is, preferring internal funding instead of external funding and choosing debt over equity (Donaldson, 1961; Myers \& Majluf, 1984). According to the theory, raising equity is not worthy because managers know more about a firm and its prospects, but the outside investors do not (information asymmetry). Those investors may discount the firm's stock price if managers issue more equity 
instead of debt. To avoid such unnecessary discounts, managers avoid equity as far as possible, whenever internal financing is insufficient to fund capital expenditures. The assumption is that managers act in the best interest of existing shareholders, and refuse to issue undervalued shares to new investors (as cited in Myers, 2001).

Free Cash Flow Theory (FCFT) introduced by Jensen (1986) discusses that when a firm generates free cash flow, conflicts between shareholders and managers arise over dividend payout policies. The challenge is to motivate managers to distribute free cash flow among the shareholders, instead of using the cash in inefficient organizational activities (M. C. Jensen, 1986). Therefore, debt can be used as a mechanism that monitors the activities of managers and encourages them to run the organization more competently, while lowering the risk of bankruptcy (M. C. Jensen, 1986; as cited in Myers, 2001).

FCFT also states that increase in firm leverage can create a threat of financial distress, however, it maximizes the value of a firm if the firm's operating cash flow substantially surpasses its profitable investment prospects. If debt is completely risk-free, debtholders would have no concern for either income or value of their investment firm. However, disputes between debtholders and shareholders take place when there is a risk of non-payment. Managers act in the best interest of shareholders so that shareholders can achieve economic benefits at the expense of debtholders. Managers take numerous approaches to transfer the value from debtholders to shareholders. For example, the managers can invest in riskier assets and borrow debt to pay out dividends to the shareholders. The managers can also limit the proportion of equity-financed capital investments. Furthermore, the managers may defer immediate bankruptcy or restructuring to hide financial problems from the debtholders. The debtholders, however, would have 
predicted the smart move of the managers in the initial stage of investment and would have confined them into debt contracts in accordance with rules and regulations (Myers, 2001).

Baker and Wurgler proposed "market timing theory" of capital structure in 2002. The theory states that the existing capital structure of a firm is the collective outcome of its prior attempts to "time the equity market" (Baker \& Wurgler, 2002). According to Baker \& Wurgler (2002), share (stock) price fluctuations can significantly affect a firm's capital structure and optimal capital structure does not exist. Moreover, this theory indicates that a firm issues bonds and stocks only when their market value is in a good standing. Whenever their market value is lower, they repurchase their shares from the existing shareholders (as cited in Alipour, Mohammadi, \& Derakhshan, 2015).

\subsection{International Research on Capital Structure}

Harris and Raviv (1991) and Rajan and Zingales (1995) summarized many studies and suggested that tangibility of assets, Non-Debt Tax Shields (NDTS), investment opportunities, firm size, volatility, advertisement expenses, $R \& D$ expenses, probability of bankruptcy, profitability, etc. are determinants of capital structure. Studies conducted around the globe reveal that there is no consensus on what determinants of debt ratio or capital structure are. It is possible that determinants of capital structure vary by industry, geography, or both. Those studies have proven that determinants of capital structure either share a negative or positive relationship with financial leverage. Fama and French (2002) found that there exists a positive relationship between leverage and firm size, and between dividend payout and size of the firm. If larger firms have less volatile earnings and net cash flows, it negatively affects payout ratio and leverage, as jointly predicted by Trade-off and Pecking Order Theories (Fama \& French, 2002). 
Determining an optimal capital structure for a company is a complicated subject that has perplexed many academicians and practitioners for decades (De Wet, 2006). Both debt and equity have been criticized under various assumptions. For example, debt financing is widely misunderstood as a factor increasing a firm's risk of bankruptcy (Smyth \& Hsing, 1995). On the other hand, equity financing is broadly criticized for having a dilution effect or reducing price per share (Akkranupornpong \& Kleiner, 2004). In practice, depending on the relative complexity of these two financing options, either debt or equity can overshadow the other. This view has been proven by Fluck (1998), who conducted debt versus equity analysis and found that both debt and equity can be used to finance projects with unlimited life, but equity inevitably dominates debt (Dybvig \& Wang, 2002). When a firm can borrow debt, it can also raise equity, but not the other way around. Depending on firm characteristics and their projects, firms who cannot borrow debt can still raise equity. When cash flows are steady, firms may borrow debt, issue equity, or use a combination of both. Even if cash flows are inconsistent and funds cannot be raised through debt, outside investors may still provide equity financing (Fluck, 1998). Fluck's argument supports the claim that shareholders can influence business activities but debtholders cannot (Becker et al., 2011). On the other hand, Myers (2001) strongly suggests that shareholders and debtholders have a conflict only when there is a risk of non-payment. Debtholders otherwise do not interfere in a firm's operating activities (Myers, 2001).

A firm's capital structure may change in response to an economic behavior. A research on Gulf Cooperation Council (GCC) countries have concluded that global recession decreased liquidity of firms and affected their capital structure due to increased cost of borrowing and stringent bank policies during the crisis (Sbeiti, 2010). This view has been supported by a study 
on the impact of financial crisis on capital structure decisions of firms in Sub-Saharan countries (Danso \& Adomako, 2010).

It is evident that every theory or individual study has proposed a unique set of concepts and relationships to explain determinants of capital structure. Each work was conducted within a unique empirical situation. Hence, generalizations cannot be made.

\subsection{Research Based on Canadian Data}

Davis (1987) presented a study to test the relationship between corporate tax rate and firm leverage. The analysis was performed at individual firm level using panel data. The study was inconclusive and could not find statistically significant relationship between corporate tax rate and firm leverage. The author concluded that although Canadian economy as a whole shows stability in the corporate tax and firm leverage over time, only few individual firms were found stable (Davis, 1987).

Aivazian et al. (2003) studied the impact of firm leverage on the investment decisions of Canadian publicly traded companies. The study found that leverage is negatively related to firm investment and the negative relationship was significantly stronger for firms with lower growth opportunities compared to those with higher growth opportunities (Aivazian, Ge, \& Qiu, 2003).

Mittoo and Zhang (2008) examined the capital structure of Canadian multinational corporations (MNCs) to understand the influence of country-specific factors on firm leverage. They found that Canadian MNCs have higher long-term debt ratio compared to the domestic corporations (DCs), which was opposite of their findings based on the U.S. evidence. They stated that higher leverage was associated with MNCs' expansions into the U.S. market because expansion into non-U.S. markets demonstrated insignificant impact on their leverage. Their 
findings support the idea that the key benefits for Canadian MNCs do not come from the diversification of cash flows as discussed in the traditional theories of capital structure. Instead, Canadian MNCs seem to benefit from close economic linkage with the U.S. market that provides them an easier access to the world's largest capital and product markets. They concluded that Canadian firms with access to international bond market have higher firm leverage than firms without such access (Mittoo \& Zhang, 2008).

Mittoo and Zhang (2010) further studied the impact of bond market access on firm leverage for Canadian firms. They classified the firms into two categories: high credit quality (HQ) and low credit quality (LQ). The impact on leverage was more evident for LQ firms. Their results were confirmed when they controlled individual firm's credit quality, assessed the change in firm leverage around rating initiation, and accounted for effect of firm size. The study suggested that Canada-U.S. bond market integration improves the financial flexibility and leverage for Canadian LQ firms (Mittoo \& Zhang, 2010).

Nunkoo \& Boetang (2010) studied the empirical determinants of target capital structure based on panel data from 1996 to 2004 . Their results demonstrated that profitability and asset tangibility significantly affect Canadian non-financial firms' leverage with positive correlations, whereas growth opportunities and firm size significantly but negatively influence the leverage of Canadian firms. The study also projected that Canadian firms have long-term target leverage ratios, but their speed of adjustment to the target leverage ratios is slower compared to other countries (Nunkoo \& Boateng, 2010). 
Gill and Mathur (2011) proposed that financial leverage of Canadian firms is driven by collateralized assets, profitability, effective tax rate, firm size, growth opportunities, number of subsidiaries, and industry in which the firms operate (Gill \& Mathur, 2011).

Rakhmayil and Yuce (2012) examined the long-term effect of North American Free Trade Agreement (NAFTA) on company performances across Canada, Mexico, and the U.S. The study focused on the impact of trade liberalization process on profitability, operating efficiency, capital investment, output (real sales), number of employees, firm leverage, and firm valuation. The authors discovered that output, profitability, and operating efficiency increased in all three countries after trade liberalization, and other effects varied by country. Lastly, the study suggested that NAFTA affected companies in all three countries positively, and the increment in profitability and operating efficiency of firms increased their firm value (Rakhmayil \& Yuce, 2012).

Hossain and Nguyen (2016) stated that leverage has a negative impact on financial performance of firms. According to them, the resilient financial system in Canada and stability in crude oil prices lowered the performance gap during the crisis period (2007-2009). It is possible that the plummeting crude oil prices increased the gap in the post-crisis period (Hossain \& Nguyen, 2016a). In another study, they found a strong evidence to prove that the performance gap between firms with high and low leverage was insignificant in context of Canada, during the financial crisis of 2007-2009 (Hossain \& Nguyen, 2016b).

\subsection{Trade-off Theory and Pecking Order Theory of Capital Structure}

Matemilola, Bany-Ariffin \&McGowan Jr. (2012) stated that Trade-off Theory and Pecking Order Theory are two rival theories that explain how finance managers make capital 
structure decisions (Matemilola, Bany-Ariffin, \& McGowan Jr., 2012). This study has reviewed both theories, along with prior studies on capital structure, and formulated explanatory variables to find the firm-specific determinants of capital structure across Canadian non-financial firms.

\subsubsection{Trade-off Theory:}

Minimizing cost of capital and maximizing firm value is justifiable under optimal capital structure perspective proposed by Modigliani and Miller (1958). In the capital cost arguments, shareholders are expected to demand least return when a firm's debt level is low, since the firm will be considered less risky. However, the cost of debt is substantially lower than the cost of equity due to the availability of tax shields. Therefore, firms are likely to use more debt than equity (Modigliani \& Miller, 1963). When a firm begins to add more debt to its capital structure, its WACC falls because it will be using more of a cheaper financing option. However, at a certain point, the WACC will begin to rise as both creditors and shareholders will start to believe that the firm is at a higher risk of bankruptcy and they are entitled to receive compensation for the increased level of risk in their investments (Ross et al., 2016). Hence, a firm's capital structure with an optimal debt-equity ratio maximizes its market value (Stretcher \& Johnson, 2011).

Modigliani and Miller (1963), Kraus and Litzenberger (1973), and Miller (1977) added tax-effects into the original framework proposed by Modigliani and Miller in 1958. It can be explained by Figure 1 (please see below). The figure is a diagrammatic representation of optimal capital structure when debt is associated with tax shields. It demonstrates the trade-off between debt-related tax shields and the cost of financial distress related to debt (Chen \& Strange, 2005). 


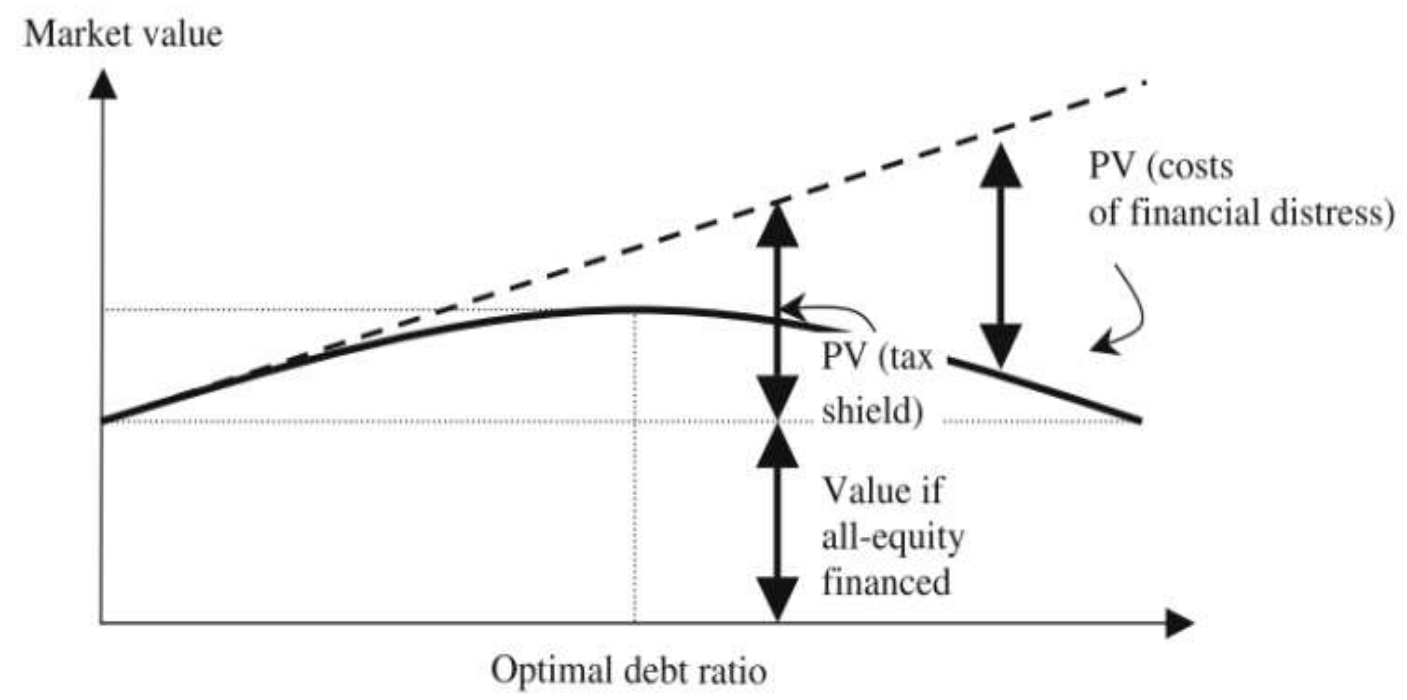

Figure 1: The Optimal Capital Structure when Debt is associated with Tax-Shield and Financial Distress Costs

The Trade-off Theory states that a firm borrows debt up until the tax-benefit from an additional dollar in debt is equivalent to the cost of financial distress as a result of the debt (Ross et al., 2016). Tax shields on debt can also be traded for the agency cost of debt, according to Jensen and Meckling (1976), who introduced Agency Theory.

\subsubsection{Pecking Order Theory:}

One of the most influential theories of corporate leverage is "Pecking Order Theory". Myers and Majluf (1984) elaborated and reintroduced the theory, which was originally developed by Donaldson in 1961. The theory states that asymmetric information affects capital structure of firms. It argues that if managers know more about their firm's value than outside parties, "the market penalizes the issuance of shares whose expected payoffs are significantly related to a firm's value per share" (Bharath, Pasquariello, \& Wu, 2009, p. 3212). This means 
that when a company issues more equity than debt, outside investors start to believe that price per share should be discounted.

Pecking Order Theory assumes that firms prefer to use internal cash instead of external funds (Myers, 2001). According to the theory, fund flow deficit at time (DEFt) can be interpreted as follows (Shyam-Sunder \& Myers, 1999):

$D E F t=D I V t+X t+\Delta W t+R t-C t$

Where,

$$
\begin{aligned}
& \mathrm{DIVt}=\text { dividend payments, } \\
& \mathrm{Xt} \quad=\text { capital expenditures, } \\
& \Delta \mathrm{Wt}=\text { net increase in working capital, } \\
& \mathrm{Rt} \quad=\text { current portion of long-term debt at start of period, } \\
& \mathrm{Ct} \quad=\text { operating cash flows, after interest and taxes, }
\end{aligned}
$$

Pecking Order Theory also assumes that when the internal cash is inadequate for real investment and dividend commitments, firms choose debt over equity because of the lower issuance cost associated with debt. Equity is rarely issued and considered to be the last resort (Frank \& Goyal, 2003).

\subsection{Theoretical Propositions of Trade-off Theory and Pecking Order Theory}

Debt ratio is the dependent variable in this research, which represents capital structure. The explanatory variables used in this research are: Age, Liquidity, Tangibility (Asset Tangibility), Size, Growth Opportunities, Profitability, and NDTS. Please refer to Table 1 for the 
theoretical propositions of Trade-off Theory and Pecking Order Theory in relation to the explanatory variables (their relationship with debt ratio) explained in the following sections:

\begin{tabular}{|l|l|c|c|}
\hline \multirow{2}{*}{ Variables } & \multicolumn{1}{c|}{ Definition } & \multicolumn{2}{c|}{ Theoretical Proposition } \\
\cline { 3 - 4 } & & $\begin{array}{c}\text { Trade-off } \\
\text { Theory }\end{array}$ & $\begin{array}{c}\text { Pecking Order } \\
\text { Theory }\end{array}$ \\
\hline Debt Ratio & Ratio of total debt to total assets & - & - \\
\hline Age & Age of a company in each fiscal year & Positive & Negative \\
\hline Liquidity & Ratio of current assets to current liabilities & Positive & Negative \\
\hline Asset Tangibility & Ratio of net fixed assets to total assets & Positive & Positive \\
\hline Size & Logarithm of total assets & Positive & Negative \\
\hline Growth Opportunities & Percentage change in total assets & Negative & Positive \\
\hline Profitability & Ratio of operating income to total assets & Positive & Negative \\
\hline Non-Debt Tax Shields & Ratio of depreciation to total assets & - & - \\
\hline
\end{tabular}

Table 1: Theoretical propositions of Trade-off Theory and Pecking Order Theory

\subsubsection{Age:}

Trade-off Theory states that there is a positive relationship between a firm's age and its ability to obtain debt, which means that older firms are considered trustworthy to qualify for debt. In contrast, Pecking Order Theory assumes a negative relationship between age and debt, meaning that older firms have better ability to hold accrued income and use it instead of debt (as cited in Mukherjee \& Mahakud, 2012).

\subsubsection{Liquidity:}

Trade-off Theory proposes that companies with higher liquidity ratios borrow more because they have short-term repayment obligations and they need to increase repaying capacity to meet the commitments. Therefore, Trade-off Theory predicts a positive relationship between 
liquidity and leverage. Alternatively, Pecking Order Theory predicts a negative relationship between liquidity and leverage because a firm with higher liquidity ratio prefers internal financing over external financing, since liquid assets can be easily transformed into cash without altering its value (as cited in Sheikh \& Wang, 2011).

\subsubsection{Asset Tangibility:}

Trade-off Theory suggests a positive relationship between asset tangibility and debt because firms' tangible assets can be used as collaterals in obtaining debt, to cover for bankruptcy. Therefore, firms with higher amount of tangible assets have a greater chance of being approved for debt. Agency Theory suggests that shareholders of highly leveraged firms have incentives to invest in their firms at sub-optimal level (there are projects that cannot be collateralized) and takeover companies' wealth from debtholders. However, debtholders would have understood the smart behavior of managers beforehand, and would have forced to keep tangible assets as collaterals against the debt (M. Jensen \& Meckling, 1976; Myers, 1977; Myers, 2001; Titman \& Wessels, 1988). In addition, Pecking Order Theory also proposes a positive relationship between asset tangibility and debt. There are costs associated with issuing shares, about which managers of firms have more information than outsiders. Therefore, firms find it more advantageous to borrow debt than issuing shares (Myers \& Majluf, 1984). Asset tangibility increases the possibility of putting collaterals, which can also avoid information asymmetry cost because the values of tangible assets are known in advance (Michaelas, Chittenden, \& Poutziouris, 1999). Since both theories suggest positive relationship between asset tangibility and debt, it will not provide a direction to conclude whether it is Trade-off Theory or Pecking Order Theory that applies to Canadian non-financial firms. 


\subsubsection{Size:}

According to Trade-off Theory, larger firms have a higher chance of being approved for debt because of their better credit rating. Larger firms can access credit markets with ease and they have better negotiating power while borrowing, unlike smaller firms (Wiwattanakantang, 1999). In other words, diversified businesses imply less likelihood of bankruptcy because of their market reputation. However, Pecking Order Theory asserts that firm size and debt have a negative relationship. As per the theory, larger firms borrow less because they are more stable, less volatile in terms of cash flow, and able to take advantage of economies of scale. They can use internal funding for their operating activities (Titman \& Wessels, 1988; Rajan \& Zingales, 1995; Gaud, Jani, Hoesli, \& Bender, 2005).

\subsubsection{Growth Opportunities:}

Trade-off Theory proposes a negative relationship between growth opportunities and debt. This is because growth opportunities are like intangible assets that cannot be collateralized to obtain debt (as cited in Sheikh \& Wang, 2011). Conversely, Pecking Order Theory suggests a positive relationship between growth opportunities and debt. Internal funds decrease when firms expand, and then the firms choose debt over equity as a financing option. The preference of debt over equity to finance growth opportunities is because of information asymmetry cost associated with issuing shares (Viviani, 2008).

\subsubsection{Profitability:}

Trade-off Theory assumes a positive relationship between profitability and debt because profitable firms are more likely to be approved for debt due to market reputation. Profitable firms 
borrow debt, primarily to take advantage of tax shields. On contrary, Pecking Order Theory conjectures a negative relationship between profitability and debt, meaning that profitable firms have higher retained earnings and they prefer internal financing over external financing (as cited in Sheikh \& Wang, 2011).

Several empirical studies (Toy, Stonehill, Remmers, Wright, \& Beekhuisen, 1974; Titman \& Wessels, 1988; Rajan \& Zingales, 1995; Booth, Aivazian, Demirguc-Kunt, \& Maksimovic, 2001; Viviani, 2008, etc.) have reported a negative relationship between profitability and debt.

\subsubsection{Non-Debt Tax Shields (NDTS):}

Non-Debt Tax Shields (NDTS) is a concept proposed by DeAngelo and Masulis (1980), which is an alternative and less risky means of reducing income taxes (Cloyd, Limberg, \& Robinson, 1997). Trade-off Theory and Pecking Order Theory do not have propositions related to NDTS because these theories were introduced before the concept of NDTS. However, the relationship between NDTS and debt has been explained by empirical works. Viviani (2008) found a significant negative relationship between NDTS and debt ratio of a firm. On contrary, Bradley et al. (1984) found a strong positive relationship between NDTS and leverage. On the other hand, Titman and Wessels (1988) found no correlation between NDTS and leverage (debt ratio) of a firm. 


\section{CHAPTER 3: METHODOLOGY}

\subsection{Research Objective}

The purpose of this study is to determine the significance of firm-specific variables, such as size, age, profitability, asset tangibility, liquidity, growth opportunities, and NDTS in determining capital structure (debt ratio) of Canadian non-financial firms. The study also examines whether there have been differences in Canadian non-financial firms' borrowing pattern before the global financial crisis (1999 to 2006), during the crisis (started in late 2007 and lasted until mid-2009), and after the crisis (2010 to 2016). Finally, the study attempts to see whether it is Trade-off Theory or Pecking Order Theory that is more applicable in the context of Canadian non-financial firms.

The research objective can be translated into three research questions:

1. What variables are statistically significant to Canadian non-financial firms' financial leverage?

2. Are there any differences in factors affecting capital structure decisions of Canadian nonfinancial firms before, during, and after the global financial crisis of 2007 - 2009 ?

3. Which theory of capital structure, i.e. Trade-off or Pecking Order is more applicable in the context of Canadian non-financial firms?

\subsection{Research Approach}

This research focuses on debt ratio (proportion of total debt in firms' total assets) that Canadian non-financial firms use to maximize enterprise value, which is consistent with the idea of economic stability and control suggested by the functionalist paradigm. Functionalists' 
approach to social science originated from the tradition of positivism (Bowring, 2000).

Positivism states that "scientific theories can be assessed objectively by reference to empirical evidence" (Ardalan, 2003, p. 201).

Discovering a set of concepts and relationships from pre-existing theoretical models to explain the behavior of some phenomena of interest is logic of deductive strategy. "Deductive strategy can also be perceived as processing the premise information at the ratio level of exactness" (Verweij, Sijtsma, \& Koops, 1999, p. 243). Since this study reviews prior works and theories, it is a deductive research that aligns with functionalist paradigm.

\subsection{Data Collection}

The sample consists of 208 firms listed on Toronto Stock Exchange (TSX) for the period of 1999 to 2016 . The research period has been chosen to study the corporate borrowing pattern in Canadian non-financial firms; before, during, and after the financial crisis of 2007-2009. The Complete Financial Statements and Ratios of sample firms were retrieved from CompustatCapital IQ (accessible via Wharton Research Data Services or WRDS) for fiscal year 1999 to 2016 ${ }^{1}$. Companies that were delisted from TSX between 1999 and 2016 are excluded from the analysis, to ensure consistency. Moreover, companies with missing financial statements in one or more fiscal years from 1999 to 2016 and the companies with missing variables in their reporting are also excluded from this study. It has been verified that all the companies were listed under TSX during the period of observation, by mapping the company names against TSX Listed

\footnotetext{
${ }^{1}$ Conditional statements used to filter the companies: Foreign Incorporation Code $=$ CAN (Data in native currency i.e. Canadian Dollars) and Stock Exchange Code $=7$ (TSX)
} 
Issuers - Market Intelligent Group (MIG) archives (https://www.tsx.com/listings/current-marketstatistics/mig-archives). Please refer to Appendix A for the full list of sample firms.

The sample excluded financial firms, banks, and insurance companies because their capital structure and characteristics are different from other businesses. Additionally, real estate firms are also excluded from the study because of market unpredictability.

The industry classifications (based on TSX archives) of 208 firms used in this research are presented in Table 2.

\begin{tabular}{|l|c|c|}
\hline \multicolumn{1}{|c|}{ Industry } & No. of Companies & Percentage Coverage (\%) \\
\hline Clean Technology & 11 & 5.29 \\
\hline Communication \& Media & 13 & 6.25 \\
\hline Diversified Industries & 80 & 38.46 \\
\hline Forest Products \& Paper & 7 & 3.37 \\
\hline Life Sciences & 17 & 8.17 \\
\hline Mining & 35 & 16.83 \\
\hline Oil \& Gas & 19 & 9.13 \\
\hline Technology & 16 & 7.69 \\
\hline Utilities \& Pipelines & 10 & 4.81 \\
\hline
\end{tabular}

Table 2: Industry classifications of the companies in sample data

\subsection{Firm-Specific Factors Affecting Capital Structure (Debt Ratio)}

The existing literature has different explanations for capital structure. According to M\&M theory, capital structure is the market value of debt over market value of equity. Since market value is difficult to measure, many researchers, such as Myers (1977), and Rajan and Zingales (1995) explained capital structure by the ratio of total liabilities to total assets. Gaud et 
al. (2005) implemented the ratio of total liabilities over total equity as a representation of capital structure or leverage (Gaud et al., 2005). In this study, Debt Ratio (total debt divided by total assets) is used as a representation of capital structure. This is consistent with many empirical works done in capital structure, including the research by Sheikh and Wang (2011). In this study, total debt is calculated by subtracting deferred taxes from total liabilities for each firm and each year included in the sample set.

The firm-specific variables affecting Debt Ratio (DR) were selected through the review of available literature and theories in the area of capital structure. The variables affecting financial leverage (DR) of firms, as suggested by two contradictory theories (Trade-off and Pecking Order) and empirical studies in capital structure, are: Age (AGE), Liquidity (LIQ), Asset Tangibility (TANG), Size (SIZE), Growth Opportunities (GROW), Profitability (PROF), and Non-Debt Tax Shields (NDTS). The definitions of explanatory variables used in this research have also been guided by the capital structure literature. They are explained below:

\subsubsection{Age (AGE):}

Age (AGE) of a company in each fiscal year has been calculated by subtracting its date of incorporation from each fiscal year. For a company incorporated in 1995, its age in fiscal year 1999 would be 4 years (i.e. 1999 -1995 = 4). Incorporation dates of companies were obtained from Mergent Online (https://www.mergentonline.com).

\subsubsection{Liquidity (LIQ):}

Based on available theories and literatures in capital structure, liquidity (LIQ) is one of the important factors that determine capital structure of firms. Prior works and available theories have different views on the relationship between liquidity and debt (capital structure). 
There are two types of liquidity ratios: current ratio and quick ratio (also known as acidtest ratio). Unlike current ratio, quick ratio does not include inventories from balance sheet. In this study, current ratio i.e., ratio of current assets to current liabilities is used as a measure of liquidity (LIQ).

\subsubsection{Asset Tangibility (TANG):}

Asset tangibility in this research refers to fixed assets of a firm that can be collateralized. Fixed assets cannot be easily converted into cash. In balance sheets, fixed assets are referred as "Property, Plant, and Equipment" or PPE. For this research, asset tangibility is measured as a ratio of net fixed assets (PPE after deducting depreciation) to total assets, as suggested by Sheikh and Wang (2011).

\subsubsection{Size (SIZE):}

Firm size (SIZE) is one of the most common determinants of capital structure. Firm size influences a firm's capability to obtain debt (Sayılgan, Karabacak, \& Küçükkocaolu, 2006).

The capital structure literature most commonly uses two variables to represent the company size: logarithm of sales and logarithm of total assets. In this research, logarithm of total assets is used as a representation of company size because total assets fluctuate less compared to total sales.

\subsubsection{Growth Opportunities (GROW):}

Growth Opportunities (GROW) has been measured by different authors in different ways. For example, Rajan and Zingales (1995), Gaud et al. (2005) and Sbeiti (2010) have applied the market-to-book ratio as a representation of growth opportunities. Some other scholars have measured growth opportunities by taking percentage change in book value of total assets (Hsiao, 
2003; Buferna, Bangassa, \& Hodgkinson, 2005). Titman and Wessels (1988) also measured growth opportunities as a percentage change in total assets. In this study as well, percentage change in total assets is used as a measure of growth opportunities.

For the calculation of percentage change in total assets of sample firms in 1999, the data for 1998 was obtained from S\&P Capital-IQ.

\subsubsection{Profitability (PROF):}

Profitability (PROF) is one of the key factors driving capital structure decisions. Scholars like Titman and Wessels (1988), Harris and Raviv (1991), and Rajan and Zingales (1995) have stated a significant negative relationship between profitability and debt ratio. This study defines profitability as a ratio of operating income (after depreciation) to total assets.

\subsubsection{Non-Debt Tax Shields (NDTS):}

There are some of expenses that can generate tax shields. Depreciation is a type of expense that can be considered tax deductible. Following López-Gracia, and José Sogorb-Mira, Francisco (2008), the ratio of depreciation to total assets has been used as a measure of NDTS (López-Gracia \& Sogorb-Mira, 2008), in this study.

Based on majority of variables' relationships with debt ratio, it will be determined whether the theoretical propositions of Trade-off Theory or Pecking Order Theory apply in the context of Canadian non-financial firms. Please refer to second chapter for theoretical propositions of Trade-off Theory and Pecking Order Theory. 


\subsection{Panel Data Analysis}

Panel data analysis has been used to examine the effect of firm-specific factors in determining capital structure of Canadian non-financial firms. Panel data analysis is preferred when the data has both cross-section dimension and time-series dimension. It is also known as longitudinal data and is formed when same samples are observed over two or more periods of time. Baltagi (2005) states that panel data analysis is "the pooling of observations on a crosssection of households, countries, firms, etc. over multiple time periods" (Baltagi, 2005, p. 1). According to Baltagi, time-series data alone are at high risk of creating multicollinearity but adding cross-section dimension to it generates "more variability, less collinearity, more degrees of freedom, and more efficiency in yielding reliable outcomes" (2005, p. 5). Baltagi further adds that panel data controls for individual heterogeneity, and therefore does not run the risk of obtaining bias results (2005, p. 4).

There are two types of panel data: balanced panel data and unbalanced panel data. Balanced panel data analyses two or more cross-sections with an equal number of time periods, whereas unbalanced panel data analyses two or more cross-sections with unequal number of time periods (Baltagi, 2005).

This research uses balanced panel data because all of 208 companies were observed from 1999 to 2016. The analysis was performed using a prominent statistical analytical tool i.e. SAS (version 9.4). The study analyses the significance of firm-specific factors in determining capital structure of Canadian non-financial firms from fiscal year 1999 to 2016 (overall period analysis), along with the analysis before the financial crisis period (1999 to 2006), during the financial crisis period (2007 to 2009), and after the crisis period (2010 to 2016). 


\subsubsection{One-Way Error Component Regression:}

This study uses a one-way error component regression for the disturbances. The description of the two models; fixed effects and random effects (for one-way error component) are given below in equation (1) and (2), respectively:

$\mathrm{DR}_{\mathrm{jt}}=\beta_{0 \mathrm{j}}+\beta_{1} \mathrm{AGE}_{\mathrm{jt}}+\beta_{2} \mathrm{LIQ}_{\mathrm{jt}}+\beta_{3} \mathrm{TANG}_{\mathrm{jt}}+\beta_{4} \mathrm{SIZE}_{\mathrm{jt}}+\beta_{5} \mathrm{GROW}_{\mathrm{jt}}+\beta_{6} \mathrm{PROF}_{\mathrm{jt}}+\beta_{7} \mathrm{NDTS}_{\mathrm{jt}}+\mu_{\mathrm{jt}}$

$\mathrm{DR}_{\mathrm{jt}}=\beta_{0}+\beta_{1} \mathrm{AGE}_{\mathrm{jt}}+\beta_{2} \mathrm{LIQ}_{\mathrm{jt}}+\beta_{3} \mathrm{TANG}_{\mathrm{jt}}+\beta_{4} \mathrm{SIZE}_{\mathrm{jt}}+\beta_{5} \mathrm{GROW}_{\mathrm{jt}}+\beta_{6} \mathrm{PROF}_{\mathrm{jt}}+\beta_{7} \mathrm{NDTS}_{\mathrm{jt}}+\varepsilon_{\mathrm{jt}}+\mu_{\mathrm{jt}}$

In the above equations:

- $\quad \mathrm{DR}_{\mathrm{jt}}$ is the measure of leverage (Debt Ratio) of firm $\mathrm{j}$ in year $\mathrm{t}$

- $\quad \beta_{0 \mathrm{j}}$ is the $\mathrm{y}$-intercept of firm $\mathrm{j}$

- $\mathrm{AGE}_{\mathrm{j} t}, \mathrm{LIQ}_{\mathrm{j}}, \mathrm{TANG}_{\mathrm{jt}}, \mathrm{SIZE}_{\mathrm{j} t}, \mathrm{GROW}_{\mathrm{jt}}, \mathrm{PROF}_{\mathrm{jt}}, \mathrm{NDTS}_{\mathrm{jt}}$ are the firm-specific factors determining leverage of firm $\mathrm{j}$ in year $\mathrm{t}$

- $\quad \beta_{1}$ to $\beta_{7}$ are coefficients of the explanatory variables

- $\quad \beta_{0}$ is a common y-intercept

- $\varepsilon_{\mathrm{jt}}$ is the remainder stochastic disturbance term for firm $\mathrm{j}$ in year $\mathrm{t}$

- $\quad \mu_{\mathrm{jt}}$ is the unobservable individual-specific effect of firm $\mathrm{j}$ in year $\mathrm{t}$

Hausman test has been used to select the model that best explains the relationship between dependent variable and explanatory variables. It is further discussed in the following chapter.

\subsubsection{Test Models for Two-Way Error Component Regression:}

Following are the test models for two-way fixed effects and two-way random effects, respectively.

$$
\begin{aligned}
& \mathrm{DR}_{\mathrm{jt}}=\beta_{0 \mathrm{j}}+\beta_{1} \mathrm{AGE}_{\mathrm{jt}}+\beta_{2} \mathrm{LIQ}_{\mathrm{jt}}+\beta_{3} \text { TANG }_{\mathrm{jt}}+\beta_{4} \text { SIZE }_{\mathrm{jt}}+\beta_{5} \mathrm{GROW}_{\mathrm{jt}}+\beta_{6} \mathrm{PROF}_{\mathrm{jt}}+\beta_{7} \mathrm{NDTS}_{\mathrm{jt}}+\mu_{\mathrm{jt}}+\lambda_{\mathrm{t}} \\
& \mathrm{DR}_{\mathrm{jt}}=\beta_{0}+\beta_{1} \mathrm{AGE}_{\mathrm{jt}}+\beta_{2} \mathrm{LIQ}_{\mathrm{jt}}+\beta_{3} \mathrm{TANG}_{\mathrm{jt}}+\beta_{4} \mathrm{SIZE}_{\mathrm{jt}}+\beta_{5} \mathrm{GROW}_{\mathrm{jt}}+\beta_{6} \mathrm{PROF}_{\mathrm{jt}}+\beta_{7} \mathrm{NDTS}_{\mathrm{jt}}+\varepsilon_{\mathrm{jt}}+\mu_{\mathrm{jt}}+\lambda_{\mathrm{t}}
\end{aligned}
$$


In equations (3) and (4), $\lambda_{t}$ denotes the unobservable time effect. Everything else remains the same as in equations (1) and (2).

\subsubsection{Test Models for Fixed Effects Dummy Variable Regression:}

Following are the fixed effects models with dummy variables. Equation (5) controls for heterogeneity (one-way fixed effects model). Equation (6) does not control for firm-specific effects but accounts for time effects only. It is known as fixed one-time model. Equation (7) is the two-way fixed effects model, which accounts for any time varying effects, while controlling for firm-specific aspects.

$$
\begin{aligned}
& \mathrm{DR}_{\mathrm{jt}}=\beta_{0 \mathrm{j}}+\beta_{1} \mathrm{AGE}_{\mathrm{jt}}+\beta_{2} \mathrm{LIQ}_{\mathrm{jt}}+\beta_{3} \mathrm{TANG}_{\mathrm{jt}}+\beta_{4} \mathrm{SIZE}_{\mathrm{jt}}+\beta_{5} \mathrm{GROW}_{\mathrm{jt}}+\beta_{6} \mathrm{PROF}_{\mathrm{jt}}+\beta_{7} \mathrm{NDTS}_{\mathrm{jt}}+\mu_{\mathrm{jt}} \\
& +\beta_{8} \mathrm{I} 1_{\mathrm{t}}+\beta_{9} \mathrm{I}_{\mathrm{t}}+\beta_{10} \mathrm{I} 3_{\mathrm{t}}+\beta_{11} \mathrm{I} 4_{\mathrm{t}}+\beta_{12} \mathrm{I} 5_{\mathrm{t}}+\beta_{13} \mathrm{I}_{\mathrm{t}}+\beta_{14} \mathrm{I} 7_{\mathrm{t}}+\beta_{15} \mathrm{I} 8_{\mathrm{t}} \\
& \mathrm{DR}_{\mathrm{jt}}=\beta_{0 \mathrm{j}}+\beta_{1} \mathrm{AGE}_{\mathrm{jt}}+\beta_{2} \mathrm{LIQ}_{\mathrm{jt}}+\beta_{3} \mathrm{TANG}_{\mathrm{jt}}+\beta_{4} \mathrm{SIZE}_{\mathrm{jt}}+\beta_{5} \mathrm{GROW}_{\mathrm{jt}}+\beta_{6} \mathrm{PROF}_{\mathrm{jt}}+\beta_{7} \mathrm{NDTS}_{\mathrm{jt}}+\lambda_{\mathrm{t}}+\beta_{8} \mathrm{I} 1_{\mathrm{t}}+\beta_{9} \mathrm{I}_{\mathrm{t}} \\
& +\beta_{10} \mathrm{I} 3_{\mathrm{t}}+\beta_{11} \mathrm{I} 4_{\mathrm{t}}+\beta_{12} \mathrm{I} 5_{\mathrm{t}}+\beta_{13} \mathrm{I} 6_{\mathrm{t}}+\beta_{14} \mathrm{I} 7_{\mathrm{t}}+\beta_{15} \mathrm{I} 8_{\mathrm{t}} \\
& \mathrm{DR}_{\mathrm{jt}}=\beta_{0 \mathrm{j}}+\beta_{1} \mathrm{AGE}_{\mathrm{jt}}+\beta_{2} \mathrm{LIQ}_{\mathrm{jt}}+\beta_{3} \mathrm{TANG}_{\mathrm{jt}}+\beta_{4} \mathrm{SIZE}_{\mathrm{jt}}+\beta_{5} \mathrm{GROW}_{\mathrm{jt}}+\beta_{6} \mathrm{PROF}_{\mathrm{jt}}+\beta_{7} \mathrm{NDTS}_{\mathrm{jt}}+\mu_{\mathrm{jt}}+\lambda_{\mathrm{t}}+\beta_{8} \mathrm{I} 1_{\mathrm{t}} \\
& +\beta_{9} \mathrm{I} 2_{\mathrm{t}}+\beta_{10} \mathrm{I}_{\mathrm{t}}+\beta_{11} \mathrm{I}_{\mathrm{t}}+\beta_{12} \mathrm{I}_{\mathrm{t}}+\beta_{13} \mathrm{I}_{\mathrm{t}}+\beta_{14} \mathrm{I}_{\mathrm{t}}+\beta_{15} \mathrm{I}_{\mathrm{t}}
\end{aligned}
$$

In the above equations:

- $\quad \mathrm{I} 1_{\mathrm{t}}$ to $\mathrm{I} 8_{\mathrm{t}}$ represent Industry dummy variables $(\mathrm{N}-1$; where $\mathrm{N}$ are number of unique values i.e. Technology, Diversified Industries, Oil \& Gas, Life Sciences, Mining, Utilities \& Pipelines, Clean Technology, Communication \& Media, and Forest Products \& Paper) in year $\mathrm{t}$

- $\quad \beta_{8}$ to $\beta_{15}$ are coefficients of the dummy variables

- $\lambda_{t}$ denotes the unobservable time effect

- $\quad \mu_{\mathrm{jt}}$ is the unobservable individual-specific effect of firm $\mathrm{j}$ in year $\mathrm{t}$ 


\section{CHAPTER 4: ANALYSIS OF RESULTS}

This chapter summarizes the panel data estimation results. One-way fixed effects model was performed on the balanced panel data of 208 Canadian non-financial firms using SAS 9.4, followed by one-way random effects model using the same statistical tool. One-way error component regression models (one-way fixed effects model and one-way random effects model) were chosen because both models account for any firm-specific but time-invariant effects. Though, fixed effects model assumes the parameters to be fixed and random effects model assumes the parameters to be random. The unobservable firm-specific effects in year ' $t$ ' is captured by $\mu_{\mathrm{j} t .}$ “"The remainder disturbance $\varepsilon_{\mathrm{jt}}$ varies with firms and time, which is a usual disturbance in the regression" (Baltagi, 2005, p. 11).

In order to decide between one-way fixed effects and one-way random effects for further analysis, Hausman test was conducted. The test helps select more efficient model against less efficient model. This study considers the significance level (alpha) of 5\%. The null hypothesis of Hausman test states that random effects model is a more efficient model. If the p-value of Hausman test is less than $0.05(5 \%)$, null hypothesis is rejected, and fixed effects model is considered a better fit.

Another test to examine whether fixed effects model is a better fit is known as "F test". The null hypothesis of the F test states that fixed effects of all observations are zero. If the pvalue is less than $0.05(5 \%)$, null hypothesis is rejected, and it is determined that fixed effects of the observations are not zero. This is when fixed effects model is considered a better fit. The outcomes of Hausman test and F test are presented in Table 3. 


\begin{tabular}{|l|c|c|c|}
\hline \multirow{2}{*}{ Data Set } & Years & \multicolumn{2}{|c|}{ Probability (p-value) } \\
\cline { 3 - 4 } & $\begin{array}{c}\text { F Test for No Fixed } \\
\text { Effects }\end{array}$ & $\begin{array}{c}\text { Hausman Test for Random } \\
\text { Effects }\end{array}$ \\
\hline Entire Period & $1999-2016$ & $<.0001$ & $<.0001$ \\
\hline Before financial crisis & $1999-2006$ & $<.0001$ & $<.0001$ \\
\hline Financial crisis & $2007-2009$ & $<.0001$ & 0.0329 \\
\hline After financial crisis & $2010-2016$ & $<.0001$ & 0.0002 \\
\hline
\end{tabular}

Table 3: Probability tests for one-way fixed effects model and one-way random effects model

The results of both tests suggest that fixed effects model is a better fit, since the probability of causing Type I error is not greater than 0.05 in all cases. Since Hausman test and F test have supported fixed effects model, further analysis in this research is based on one-way fixed effects model only.

One-way fixed effects analysis was performed in four different sets: overall period (1999 - 2016), before crisis period (1999 - 2006), crisis period (2007 - 2009), and after crisis period (2010 - 2016).

First set of analysis examined the factors affecting capital structure decision of Canadian non-financial firms from 1999 to 2016 . The R-squared is 0.3523 , which means about $35 \%$ of data was captured (please refer to Figure 2, Appendix B). According to the results, Canadian non-financial firms with higher Liquidity (LIQ) ratio, higher Profitability (PROF) ratio, and larger Size (SIZE) borrowed lower debt during the period. They were possibly using their internal funds to finance their operations. Also, companies with higher Growth Opportunities (GROW) did not borrow additional debt to accommodate changes in their operations. Moreover, higher Asset Tangibility (TANG) of a firm did not lead to use of more debt (DR), which is inconsistent with capital structure theories. Furthermore, older (AGE) companies were able to borrow more debt to finance their operations. This could be because of market reputation and the 
history of maintaining stability over the years. Non-Debt Tax Shields (NDTS) did not appear to have any effect on Canadian non-financial firms' decision to borrow debt to finance their operating activities from 1999 to 2016. Please refer to Table 4 for parameter estimates.

\begin{tabular}{|c|c|c|c|}
\hline \multicolumn{4}{|c|}{ Parameter Estimates 1999- 2016} \\
\hline Variable & Estimate $^{2}$ & Standard Error & $\operatorname{Pr}>|\mathbf{t}|^{3}$ \\
\hline Intercept & 0.542812 & 0.073800 & $<.0001$ \\
\hline AGE & 0.008876 & 0.001180 & $<.0001$ \\
\hline LIQ & -0.012320 & 0.001210 & $<.0001$ \\
\hline TANG & -0.303130 & 0.045100 & $<.0001$ \\
\hline SIZE & -0.202740 & 0.016700 & $<.0001$ \\
\hline GROW & -0.000080 & 0.000021 & $<.0001$ \\
\hline PROF & -0.014860 & 0.004280 & 0.0005 \\
\hline NDTS & -0.116710 & 0.182000 & 0.5214 \\
\hline
\end{tabular}

Table 4: Parameter estimates of one-way fixed effects model from 1999 to 2016

Second set of analysis examined the factors affecting capital structure decision of Canadian non-financial firms before the financial crisis (1999 - 2006). The R-squared is 0.4098, which means about $41 \%$ of data was captured (please refer to Figure 3, Appendix B). According to the results, higher Liquidity (LIQ) of a firm led to lower Debt Ratio (DR) during the period. It happens when firms prefer to use internal cash over external funds. Large sized companies (SIZE) also borrowed less, potentially because they had accumulated retained earnings and cash flow, which could substitute for debt. Moreover, companies with higher Growth Opportunities (GROW) could not borrow more debt. As firms grow, they are responsible to build trust to attract investors and they may not prefer higher debt that would show on their balance sheets.

\footnotetext{
${ }^{2}$ In SAS results, Coefficient Value is referred as "Estimate".

${ }^{3}$ In SAS, Pr $>|t|$ is the p-value in the two-tailed probability of t distribution.
} 
Furthermore, companies with higher net fixed assets or Asset Tangibility (TANG) had lesser DR, which is inconsistent with capital structure theories. Age (AGE), Profitability (PROF), and Non-Debt Tax Shields (NDTS) did not show any impact on Canadian non-financial firms' decision to borrow debt to finance their operating activities before the crisis period. Please refer to Table 5 for parameter estimates.

\begin{tabular}{|l|c|c|c|}
\hline \multicolumn{4}{|c|}{ Parameter Estimates 1999 - 2006 } \\
\hline Variable & Estimate & Standard Error & Pr $>|\mathbf{t}|$ \\
\hline Intercept & 0.804993 & 0.142800 & $<.0001$ \\
\hline AGE & 0.003348 & 0.004480 & 0.4548 \\
\hline LIQ & -0.008520 & 0.002010 & $<.0001$ \\
\hline TANG & -0.504450 & 0.096500 & $<.0001$ \\
\hline SIZE & -0.279890 & 0.038600 & $<.0001$ \\
\hline GROW & -0.000140 & 0.000028 & $<.0001$ \\
\hline PROF & -0.005140 & 0.005500 & 0.3505 \\
\hline NDTS & -0.335410 & 0.315900 & 0.2885 \\
\hline
\end{tabular}

Table 5: Parameter estimates of one-way fixed effects model from 1999 to 2006

Third set of analysis examined factors affecting debt borrowing decision of Canadian non-financial firms during the financial crisis period (2007 - 2009). The R-squared is 0.8933 , which means about $89 \%$ of data was captured (please refer to Figure 4, Appendix B). According to the results, firms with higher Liquidity (LIQ) ratio and that are larger in Size (SIZE) preferred using internal financing over external financing during the crisis period. This is not unusual to happen during financial crisis because that is when bank policies are stringent and access to credit market is not easy. It is unlikely that those firms issued equity instead of debt during the period because firm shares devalue during crisis periods and no firm would issue undervalued shares. On the other hand, Age (AGE), Growth Opportunities (GROW), and Non-Debt Tax Shields (NDTS) showed positive relationship with leverage or Debt Ratio (DR). This means older firms were being better approved for debt during the financial crisis period. In addition, 
firms seeking growth opportunities were borrowing more debt, possibly because their internal funds were decreasing due to expansion. NDTS showing positive relationship with DR is not consistent with the arguments by DeAngelo and Masulis (1980), who stated that NDTS should motivate corporate managers to borrow less debt in expectation of tax advantages. Moreover, Asset Tangibility (TANG) and Profitability (PROF) did not show any impact on Canadian nonfinancial firms' decision to borrow debt to finance their operating activities during the crisis period. Please refer to Table 6 for parameter estimates.

\begin{tabular}{|l|c|c|c|}
\hline \multicolumn{4}{|c|}{ Parameter Estimates 2007 - 2009 } \\
\hline Variable & Estimate & Standard Error & Pr $>|\mathbf{t}|$ \\
\hline Intercept & 0.310360 & 0.141200 & 0.0285 \\
\hline AGE & 0.015170 & 0.005110 & 0.0032 \\
\hline LIQ & -0.012910 & 0.002350 & $<.0001$ \\
\hline TANG & -0.044830 & 0.089500 & 0.6169 \\
\hline SIZE & -0.208000 & 0.053900 & 0.0001 \\
\hline GROW & 0.000280 & 0.000105 & 0.008 \\
\hline PROF & 0.037093 & 0.030000 & 0.2164 \\
\hline NDTS & 0.708282 & 0.356100 & 0.0474 \\
\hline
\end{tabular}

Table 6: Parameter estimates of one-way fixed effects model from 2007 to 2009

Final set of analysis examined the factors affecting debt borrowing decision of Canadian non-financial firms after the financial crisis period (2010 - 2016). The R-squared is 0.6274 , which means about $63 \%$ of data was captured (please refer to Figure 5, Appendix B). According to the results, firms with higher Liquidity (LIQ) ratio, larger Size (SIZE), and higher Profitability (PROF) ratio preferred using internal cash or accumulated earnings instead of debt during the period. Non-Debt Tax Shields (NDTS) showed positive relationship with leverage or DR, which is inconsistent with the arguments by DeAngelo and Masulis (1980), who stated that NDTS should substitute tax shields on debt and therefore would have negative relationship with firm 
leverage. Age (AGE), Asset Tangibility (TANG), and Growth Opportunities (GROW) did not show any impact on Canadian non-financial firms' decision to borrow debt after the crisis period. Please refer to Table 7 for parameter estimates.

\begin{tabular}{|l|c|c|c|}
\hline \multicolumn{4}{|c|}{ Parameter Estimates 2010 - 2016 } \\
\hline Variable & Estimate & Standard Error & Pr $>|\mathbf{t}|$ \\
\hline Intercept & 0.614458 & 0.113700 & $<.0001$ \\
\hline AGE & 0.000747 & 0.002770 & 0.7874 \\
\hline LIQ & -0.015950 & 0.002100 & $<.0001$ \\
\hline TANG & -0.061110 & 0.069900 & 0.3820 \\
\hline SIZE & -0.166880 & 0.036700 & $<.0001$ \\
\hline GROW & -0.000030 & 0.000060 & 0.6413 \\
\hline PROF & -0.126040 & 0.014300 & $<.0001$ \\
\hline NDTS & 0.868647 & 0.314500 & 0.0058 \\
\hline
\end{tabular}

Table 7: Parameter estimates of one-way fixed effects model from 2010 to 2016

In this study, size (SIZE) turned out to be one of the dominant determinants of capital structure from 1999 to 2016, and the period before crisis (1999-2006). The coefficient value is -0.202740 for the overall period (1999 - 2016) and -0.279890 for before crisis period (1999 2006). The results show that the relationship between size (SIZE) and Debt Ratio (DR) has consistently been significant and negative. This is consistent with Pecking Order Theory, and consistent with the studies conducted by Titman and Wessels (1988), Harris and Raviv (1991), and Rajan and Zingales (1995).

Asset Tangibility (TANG) represented a leading determinant of capital structure of Canadian non-financial firms from 1999 to 2016 and the period before crisis (1999 - 2006), with coefficient values of -0.303130 and -0.504450 , respectively.

NDTS represented another dominant factor affecting the capital structure decision of firms, during and after the financial crisis, with coefficient values of 0.708282 and 0.868647 , 
respectively. The results show a strong positive relationship between NDTS and DR during the periods. However, this is inconsistent with the study performed by renowned scholars Titman and Wessels (1988), and the arguments by DeAngelo and Masulis (1980).

Liquidity (LIQ) showed negative relationship with firm leverage (or DR) in overall period, before crisis period, during crisis period, and after crisis period. However, it did not appear as a leading or most dominant factor affecting capital structure decision of Canadian non-financial firms in all periods of analysis. The coefficient values ranged between -0.01 and -0.02 in all four sets of assessments.

To test the robustness of the results, the 208 companies were first sorted alphabetically according to their names and then distributed among 5 groups: Group 1, Group 2, Group 3, Group 4, and Group 5 (please refer to Appendix C). Then, companies that belonged to Group 2 (randomly selected) were omitted for analysis. One-way fixed effects model was employed to carry out analysis for the remaining 166 companies. Table 8 compares the results between the two analyses.

The results in Table 8 demonstrate that the relationship between the firm-specific variables and debt ratio did not change after dropping "Group 2" from the analysis. The differences in the coefficient values are insignificant. This shows that the results obtained are not driven by certain sample set or statistical artefacts. 


\begin{tabular}{|c|c|c|c|c|c|c|c|c|}
\hline \multicolumn{9}{|c|}{ Fixed One-Way Parameter Estimates 1999 - 2016} \\
\hline $\begin{array}{c}\text { No. of } \\
\text { Companies }\end{array}$ & \multicolumn{3}{|c|}{208} & \multicolumn{3}{|c|}{166} & \multirow{4}{*}{ Difference } & \multirow{4}{*}{$\begin{array}{c}\text { Difference } \\
(\%)\end{array}$} \\
\hline R-squared & \multicolumn{3}{|c|}{0.3523} & \multicolumn{3}{|c|}{0.3443} & & \\
\hline F-test & \multicolumn{3}{|c|}{$<.0001$} & \multicolumn{3}{|c|}{$<.0001$} & & \\
\hline Variable & Estimate & $\begin{array}{c}\text { Standard } \\
\text { Error }\end{array}$ & $\operatorname{Pr}>|\mathbf{t}|$ & Estimate & $\begin{array}{c}\text { Standard } \\
\text { Error }\end{array}$ & $\operatorname{Pr}>|t|$ & & \\
\hline Intercept & 0.542812 & 0.073800 & $<.0001$ & 0.561688 & 0.080300 & $<.0001$ & 0.01888 & 3.48 \\
\hline AGE & 0.008876 & 0.001180 & $<.0001$ & 0.009596 & 0.001410 & $<.0001$ & 0.00072 & 8.11 \\
\hline LIQ & -0.012320 & 0.001210 & $<.0001$ & -0.012140 & 0.001410 & $<.0001$ & 0.00018 & -1.46 \\
\hline TANG & -0.303130 & 0.045100 & $<.0001$ & -0.307520 & 0.053700 & $<.0001$ & -0.00439 & 1.45 \\
\hline SIZE & -0.202740 & 0.016700 & $<.0001$ & -0.221320 & 0.019500 & $<.0001$ & -0.01858 & 9.16 \\
\hline GROW & -0.000080 & 0.000021 & $<.0001$ & -0.000090 & 0.000024 & 0.0001 & -0.00001 & 12.50 \\
\hline PROF & -0.014860 & 0.004280 & 0.0005 & -0.013040 & 0.004690 & 0.0055 & 0.00182 & -12.25 \\
\hline NDTS & -0.116710 & 0.182000 & 0.5214 & -0.096610 & 0.215900 & 0.6545 & 0.02010 & -17.22 \\
\hline
\end{tabular}

Table 8: Robustness Analysis

If two-way error component models (two-way fixed effects and two-way random effects) were chosen for the analysis, the models would have accounted for any individual-invariant but time-specific effects that is not included in the regression (Baltagi, 2005), as reflected in equations (3) and (4). Two-way error component models are appropriate when economic variables, such as GDP, Interest Rate, Inflation etc., are included as explanatory variables.

Based on the test models for two-way error component regression (equation (3) and (4)), a major difference in results of one-way fixed effects model and two-way fixed effects model is that age (AGE) would be dropped in two-way fixed effects model because of multicollinearity. Please refer to Table 9 and Table 10. 


\begin{tabular}{|l|c|c|c|c|}
\hline \multicolumn{5}{|c|}{ Parameter Estimates 1999 - 2016 } \\
\hline \multirow{2}{*}{ Variable } & \multicolumn{2}{|c|}{ Fixed One-Way } & \multicolumn{2}{c|}{ Fixed Two-Way } \\
\cline { 2 - 5 } & Estimate & Pr $>|\mathbf{t}|$ & Estimate & Pr $>|\mathbf{t}|$ \\
\hline Intercept & 0.542812 & $<.0001$ & 0.787697 & $<.0001$ \\
\hline AGE & 0.008876 & $<.0001$ & 0.000000 &. \\
\hline LIQ & -0.012320 & $<.0001$ & -0.012340 & $<.0001$ \\
\hline TANG & -0.303130 & $<.0001$ & -0.311250 & $<.0001$ \\
\hline SIZE & -0.202740 & $<.0001$ & -0.201170 & $<.0001$ \\
\hline GROW & -0.000080 & $<.0001$ & -0.000090 & $<.0001$ \\
\hline PROF & -0.014860 & 0.0005 & -0.013780 & 0.0013 \\
\hline NDTS & -0.116710 & 0.5214 & -0.081110 & 0.6563 \\
\hline
\end{tabular}

Table 9: Difference in parameter estimates of fixed effects models (one-way and two-way) for 1999-2016

\begin{tabular}{|l|c|c|c|c|}
\hline \multicolumn{5}{|c|}{ Parameter Estimates 2007 - 2009 } \\
\hline \multirow{2}{*}{ Variable } & \multicolumn{2}{|c|}{ Fixed One-Way } & \multicolumn{2}{c|}{ Fixed Two-Way } \\
\cline { 2 - 5 } & Estimate & Pr $>|\mathbf{t}|$ & Estimate & Pr $>|\mathbf{t}|$ \\
\hline Intercept & 0.310360 & 0.0285 & 0.682214 & $<.0001$ \\
\hline AGE & 0.015170 & 0.0032 & 0.000000 &. \\
\hline LIQ & -0.012910 & $<.0001$ & -0.012480 & $<.0001$ \\
\hline TANG & -0.044830 & 0.6169 & -0.051920 & 0.5553 \\
\hline SIZE & -0.208000 & 0.0001 & -0.232500 & $<.0001$ \\
\hline GROW & 0.000280 & 0.0080 & 0.000304 & 0.0035 \\
\hline PROF & 0.037093 & 0.2164 & 0.048514 & 0.1015 \\
\hline NDTS & 0.708282 & 0.0474 & 0.694899 & 0.0476 \\
\hline
\end{tabular}

Table 10: Difference in parameter estimates of fixed effects models (one-way and two-way) for 2007-2009

Some additions were made to the data to accommodate industry dummy variables. Each industry dummy variable represented one category of the industry and was coded with 1 if the case fell in that industry, and with 0 otherwise. The Fixed Effects (FE) least squares or Least Squares Dummy Variables (LSDV) suffers from a large loss of degrees of freedom. While estimating $(\mathrm{N}-1)$ extra parameters, too many dummy variables may aggravate the problem of multicollinearity among the regression components. In addition, "the FE estimator cannot 
estimate the effect of any time-invariant variable like industry, gender, race, religion etc. These time-invariant variables are wiped out by within-estimator while calculating the deviations from means" (Baltagi, 2005, p. 13). Baltagi (2005) also states that time-invariant variables (industries in the case of this research) are spanned by the individual dummy variables, and therefore the fixed time regression model will fail, owing to perfect multicollinearity.

To validate, industry dummy variables were added to fixed effects models. The results of one-way fixed effects model (equation (5)) did not show any significance with industry dummy variables. However, when firm-specific effects were not controlled i.e. use of fixed one-time model (equation (6)), the industry effects were observed. Technology, Oil \& Gas, and Clean Technology (renewable energy) showed significance with firm leverage. The results of two-way fixed effects model (equation (7)) also did not show any significance with industry dummy variables because it also accounts for heterogeneity, like one-way fixed effects model. Please refer to Table 11. 


\begin{tabular}{|l|c|c|c|c|c|c|}
\hline \multicolumn{7}{|c|}{ Parameter Estimates 1999 - 2016 } \\
\hline \multirow{2}{*}{ Variable } & \multicolumn{2}{|c|}{ Fixed One-Way } & \multicolumn{2}{c|}{ Fixed One-Time } & \multicolumn{2}{c|}{ Fixed Two-Way } \\
\cline { 2 - 7 } & Estimate & Pr $>|\mathbf{t}|$ & Estimate & Pr $>|\mathbf{t}|$ & Estimate & Pr $>|\mathbf{t}|$ \\
\hline Intercept & 0.542812 & $<.0001$ & 0.583871 & $<.0001$ & 0.787697 &. \\
\hline AGE & 0.008876 & $<.0001$ & 0.001158 & $<.0001$ & 0.000000 & $<.0001$ \\
\hline LIQ & -0.012320 & $<.0001$ & -0.018800 & $<.0001$ & -0.012340 & $<.0001$ \\
\hline TANG & -0.303130 & $<.0001$ & -0.299500 & $<.0001$ & -0.311250 & $<.0001$ \\
\hline SIZE & -0.202740 & $<.0001$ & -0.008480 & 0.2336 & -0.201170 & $<.0001$ \\
\hline GROW & -0.000080 & $<.0001$ & -0.000040 & 0.0586 & -0.000090 & 0.0013 \\
\hline PROF & -0.014860 & 0.0005 & -0.020750 & $<.0001$ & -0.013780 & 0.6566 \\
\hline NDTS & -0.116710 & 0.5214 & 0.035779 & 0.8135 & -0.081110 & 1.0000 \\
\hline Technology & 0.000000 &. & -0.121530 & $<.0001$ & 31.054600 &. \\
\hline Diversified Industries & 0.000000 &. & 0.000000 &. & 0.000000 & 1.0000 \\
\hline Oil \& Gas & 0.000000 &. & 0.109815 & $<.0001$ & -143.683000 & 1.0000 \\
\hline Life Sciences & 0.000000 &. & 0.012282 & 0.6051 & -29.596600 & 1.0000 \\
\hline Mining & 0.000000 &. & -0.027550 & 0.1301 & -39.741200 & 1.0000 \\
\hline Utilities \& Pipelines & 0.000000 &. & 0.182314 & $<.0001$ & -34.118400 & 1.0000 \\
\hline Clean Technology & 0.000000 &. & 0.074815 & 0.0029 & -32.539100 &. \\
\hline $\begin{array}{l}\text { Communication \& } \\
\text { Media }\end{array}$ & 0.000000 &. & 0.038235 & 0.1093 & 0.000000 & 1.0000 \\
\hline $\begin{array}{l}\text { Forest Products \& } \\
\text { Paper }\end{array}$ & 0.000000 & $\cdot$ & 0.032035 & 0.2918 & 173.028000 & 1.0000 \\
\hline
\end{tabular}

Table 11: Difference in parameter estimates of fixed effects models (one-way, one-time, and twoway) with Industry Dummy Variables for 1999 to 2016

In addition, when equations (5), (6), and (7) were applied to the crisis period, the results of one-way fixed effects model (equation (5)) did not show any significance with industry. The results of two-way fixed effects model (equation (7)) also demonstrated that industry effects were insignificant. However, the results of fixed one-time (equation (6)) showed that Mining, Utilities \& Pipelines, and Technology were the industries having significant effect on firm leverage during the crisis period. This is different from the analysis of overall period as presented in Table 11. It means that the overall period did not only account for the crisis period, but also 
considered any time-specific effects that may have affected the industry, before and after the crisis period. Please refer to Table 12.

\begin{tabular}{|l|c|c|c|c|c|c|}
\hline \multicolumn{7}{|c|}{ Parameter Estimates 2007 - 2009 } \\
\hline \multirow{2}{*}{ Variable } & \multicolumn{2}{|c|}{ Fixed One-Way } & Fixed One-Time & \multicolumn{2}{c|}{ Fixed Two-Way } \\
\cline { 2 - 7 } & Estimate & Pr $>|\mathbf{t}|$ & Estimate & Pr $>|\mathbf{t}|$ & Estimate & Pr $>|\mathbf{t}|$ \\
\hline Intercept & 0.310360 & 0.0285 & 0.427789 & $<.0001$ & 0.682214 & $<.0001$ \\
\hline AGE & 0.015170 & 0.0032 & 0.000571 & 0.1536 & 0.000000 &. \\
\hline LIQ & -0.012910 & $<.0001$ & -0.013460 & $<.0001$ & -0.012480 & $<.0001$ \\
\hline TANG & -0.044830 & 0.6169 & -0.236980 & $<.0001$ & -0.051920 & 0.5588 \\
\hline SIZE & -0.208000 & 0.0001 & 0.037582 & 0.0019 & -0.232500 & $<.0001$ \\
\hline GROW & 0.000280 & 0.0080 & 0.000083 & 0.6201 & 0.000304 & 0.0038 \\
\hline PROF & 0.037093 & 0.2164 & -0.168320 & $<.0001$ & 0.048514 & 0.1045 \\
\hline NDTS & 0.708282 & 0.0474 & 0.154756 & 0.5603 & 0.694899 & 0.0496 \\
\hline Technology & 0.000000 &. & -0.096580 & 0.007 & 14.203820 & 1.0000 \\
\hline Diversified Industries & 0.000000 &. & 0.000000 &. & 0.000000 &. \\
\hline Oil \& Gas & 0.000000 &. & 0.010817 & 0.7683 & -49.062600 & 1.0000 \\
\hline Life Sciences & 0.000000 &. & 0.041240 & 0.3105 & -18.088800 & 1.0000 \\
\hline Mining & 0.000000 &. & -0.114200 & $<.0001$ & -7.370010 & 1.0000 \\
\hline Utilities \& Pipelines & 0.000000 &. & 0.210648 & $<.0001$ & -13.848300 & 1.0000 \\
\hline Clean Technology & 0.000000 &. & 0.027672 & 0.4717 & -22.799100 & 1.0000 \\
\hline $\begin{array}{l}\text { Communication \& } \\
\text { Media }\end{array}$ & 0.000000 &. & 0.025640 & 0.4819 & 0.000000 &. \\
\hline Forest Products \& Paper & 0.000000 &. & -0.034640 & 0.4562 & 79.402550 & 1.0000 \\
\hline
\end{tabular}

Table 12: Difference in parameter estimates of fixed effects models (one-way, one-time, and two-way) with Industry Dummy Variables for 2007 to 2009 


\section{CHAPTER 5: FINDINGS AND CONCLUSIONS}

This research investigates firm-specific determinants of capital structure of 208 Canadian non-financial firms listed on TSX from 1999 to 2016. This study also examines the phenomenon before, during and after the financial crisis. The analysis has been performed using a panel data technique i.e. one-way fixed effects model.

The study uses Debt Ratio (DR) as a dependent variable. Age (AGE), Liquidity (LIQ), Asset Tangibility (TANG), Size (SIZE), Growth Opportunities (GROW), Profitability (PROF), and Non-Debt Tax Shields (NDTS) are the explanatory variables. Based on the overall analysis from 1999 to 2016, Liquidity (LIQ), Size (SIZE), and Profitability (PROF) negatively affected Debt Ratio (DR). These correlations can be translated into a fact that firms preferred internal financing over debt during those years. Firms having higher Growth Opportunities (GROW) borrowed less debt, possibly because they wanted to maintain financial statements with lesser debt to attract new investors. Firms with older Age (AGE) borrowed more debt during the period, whereas Non-Debt Tax Shields (NDTS) did not show any significance with Debt Ratio (DR). Asset Tangibility (TANG) showed negative relationship with DR, which is not consistent with capital structure theories and prior studies.

As the analysis was split into three different periods; before, during and after the crisis, some consistencies and some pattern changes were observed. Liquidity (LIQ) showed negative relationship with Debt Ratio (DR) in all periods. It means that cash convertible assets can substitute for debt at any time. Size (SIZE) of the firm reflected significant negative relationship with DR in all periods. Large sized companies (SIZE) borrowed less debt, probably because of their preference to use internal funds instead of debt. Growth Opportunities (GROW) appeared to 
be the most volatile factor affecting borrowing decision of Canadian non-financial firms. The relationship between Growth Opportunities (GROW) and leverage (or DR) appeared to be negative and extremely weak for overall period (1999 - 2016) and before crisis period (1999 2006), with coefficient value less than -0.0002 in each period. The relationship was positive but negligible during the crisis period (2007 - 2009), with the coefficient value less than 0.0003 . The variable (GROW) did not show any significance with DR after the crisis period (2010 - 2016).

During the crisis period, older (AGE) firms were obtaining debt more easily, and this is likely because of their stability and market reputation. Moreover, firms seeking Growth Opportunities (GROW) were borrowing more debt during the period, probably because their internal funds were becoming insufficient for expansion. NDTS showed positive relationship with DR, which is inconsistent with the arguments by DeAngelo and Masulis (1980). Furthermore, Asset Tangibility (TANG), and Profitability (PROF) did not show any impact on Canadian non-financial firms' decision to use leverage for financing their operating activities during the crisis period.

Firms with higher Liquidity (LIQ) ratio and that are larger in Size (SIZE) preferred using internal financing over external financing during the crisis period. This happens during financial crisis because bank policies are tighter during such times. It is extremely unlikely for firms to issue equity instead of debt during recession time because share prices devalue during recession and no firm would issue shares at discounted price.

Although, the results for different set of analysis performed (overall, before crisis, during crisis, and after crisis) are not similar, it can be concluded that age, liquidity, asset tangibility, size, growth opportunities, and profitability are significant determinants of capital structure in 
Canadian non-financial firms. Even though NDTS showed significance in some periods of the analysis, its relationship being positive with debt ratio is not consistent with arguments by DeAngelo and Masulis (1980). Therefore, NDTS could not be considered as one of the determinants of capital structure in the context of Canadian non-financial firms.

The analyses performed for all four sets suggest that Pecking Order Theory is more applicable in the context of Canadian non-financial firms. However, Trade-off Theory cannot be ignored completely because some hypotheses of Trade-off Theory also seemed applicable. This is consistent with the findings of Fama and French (2002), who stated that both theories have abilities to explain some aspects of capital structure decisions. Therefore, one theory cannot be ignored in support of another theory (Fama \& French, 2002).

This research contributes to the existing literature on capital structure in Canada, by analyzing the data into three different periods: before crisis, during crisis, and after crisis. This study may be helpful for finance managers, financial advisors, investors, and academicians who are interested to gather knowledge about how determinants of capital structure varied across Canadian non-financial firms in response to the global economic situation. There are certain limitations to the study, which are discussed in chapter 6. 


\section{CHAPTER 6: LIMITATIONS AND SCOPE OF FUTURE RESEARCH}

Capital structure decisions depend on a complex mixture of theoretical frameworks and practical considerations. At managerial level, it is unrealistic to base decisions purely on a specific theory or propositions. Theories and literature provide a knowledge of capital structure; however, the decision is often driven by practical limitations (Stretcher \& Johnson, 2011). This is a limitation of any capital structure research, and it applies to this study as well. Moreover, the potential impacts of managerial traits and personal preferences on capital structure (Hackbarth, 2008), and the impacts of CEO qualifications on capital structure choices (Rakhmayil \& Yuce, 2008) are beyond the scope of this research.

Financial firms are excluded from this study because the structures of their financial statements differ significantly from that of non-financial firms. Nevertheless, the methodologies used in this research can be replicated by shifting the focus on Canadian financial firms. Future research can also examine difference in capital structure determinants across Canadian non-financial firms by industry. 
APPENDICES 


\section{Appendix A: List of Companies from Research Data}

\begin{tabular}{|c|c|c|}
\hline S. No. & Company Name & $\begin{array}{l}\text { Date of } \\
\text { Incorporation }\end{array}$ \\
\hline 1 & Absolute Software Corporation & 1993 \\
\hline 2 & ADF Group Inc. & 1956 \\
\hline 3 & Advantage Oil \& Gas Ltd. & 1979 \\
\hline 4 & Aecon Group Inc. & 1957 \\
\hline 5 & AEterna Zentaris Inc. & 1990 \\
\hline 6 & AgJunction Inc. & 1990 \\
\hline 7 & Agnico Eagle Mines Limited & 1972 \\
\hline 8 & Agrium Inc. & 1992 \\
\hline 9 & AirBoss of America Corp. & 1989 \\
\hline 10 & Akita Drilling Ltd. & 1992 \\
\hline 11 & Alamos Gold Inc. & 1994 \\
\hline 12 & Algoma Central Corporation & 1899 \\
\hline 13 & Almaden Minerals Ltd. & 1980 \\
\hline 14 & AltaGas Ltd. & 1994 \\
\hline 15 & Aptose Biosciences Inc. & 1986 \\
\hline 16 & Aralez Pharmaceuticals Inc. & 1996 \\
\hline 17 & ARC Resources Ltd. & 1996 \\
\hline 18 & Atco Ltd. & 1962 \\
\hline 19 & Aurinia Pharmaceuticals Inc. & 1993 \\
\hline 20 & Badger Daylighting Ltd. & 1992 \\
\hline 21 & Ballard Power Systems Inc. & 1983 \\
\hline 22 & Barrick Gold Corporation & 1984 \\
\hline 23 & Baytex Energy Corp. & 1993 \\
\hline 24 & BCE Inc. & 1970 \\
\hline 25 & BELLUS Health Inc. & 1993 \\
\hline 26 & Big Rock Brewery Inc. & 1985 \\
\hline 27 & Bird Construction Inc. & 1930 \\
\hline 28 & BlackBerry Limited & 1984 \\
\hline 29 & BMTC Group Inc. & 1989 \\
\hline 30 & Bombardier Inc. & 1902 \\
\hline 31 & Bonavista Energy Corporation & 1987 \\
\hline 32 & Bonterra Energy Corp. & 1981 \\
\hline 33 & Boralex Inc. & 1982 \\
\hline 34 & Boyd Group Services Inc. & 1997 \\
\hline
\end{tabular}




\begin{tabular}{|c|c|c|}
\hline S. No. & Company Name & $\begin{array}{l}\text { Date of } \\
\text { Incorporation }\end{array}$ \\
\hline 35 & Brampton Brick Limited & 1950 \\
\hline 36 & Brick Brewing Co. Limited & 1984 \\
\hline 37 & Buhler Industries Inc. & 1994 \\
\hline 38 & Caldwell Partners International Inc. (The) & 1979 \\
\hline 39 & Calfrac Well Services Ltd. & 1960 \\
\hline 40 & Calian Group Ltd. & 1982 \\
\hline 41 & Cameco Corporation & 1987 \\
\hline 42 & Canadian National Railway Company & 1919 \\
\hline 43 & Canadian Natural Resources Limited & 1973 \\
\hline 44 & Canadian Pacific Railway Limited & 1881 \\
\hline 45 & Canadian Tire Corporation Limited & 1927 \\
\hline 46 & Canam Group Inc. & 1997 \\
\hline 47 & Canfor Corporation & 1966 \\
\hline 48 & Cardiome Pharma Corp. & 1986 \\
\hline 49 & Cascades Inc. & 1964 \\
\hline 50 & Cathedral Energy Services Ltd. & 1987 \\
\hline 51 & CCL Industries Inc. & 1951 \\
\hline 52 & Celestica Inc. & 1996 \\
\hline 53 & CGI Group Inc. & 1981 \\
\hline 54 & Cogeco Communications Inc. & 1957 \\
\hline 55 & Cogeco Inc.-SUB VTG & 1957 \\
\hline 56 & Computer Modelling Group Ltd. & 1996 \\
\hline 57 & Corby Spirit and Wine Limited & 1924 \\
\hline 58 & Corus Entertainment Inc. & 1998 \\
\hline 59 & Cott Corporation & 1955 \\
\hline 60 & Descartes Systems Group Inc. (The) & 1981 \\
\hline 61 & Dominion Diamond Corporation & 1980 \\
\hline 62 & Dorel Industries Inc. & 1962 \\
\hline 63 & Dundee Precious Metals Inc. & 1983 \\
\hline 64 & Electrovaya Inc. & 1996 \\
\hline 65 & Emera Incorporated & 1919 \\
\hline 66 & Enbridge Inc. & 1970 \\
\hline 67 & Encana Corporation & 1947 \\
\hline 68 & Enghouse Systems Limited & 1984 \\
\hline 69 & Ensign Energy Services Inc. & 1987 \\
\hline 70 & Exco Technologies Limited & 1986 \\
\hline
\end{tabular}




\begin{tabular}{|c|c|c|}
\hline S. No. & Company Name & $\begin{array}{l}\text { Date of } \\
\text { Incorporation }\end{array}$ \\
\hline 71 & EXFO Inc. & 1985 \\
\hline 72 & Fennec Pharmaceuticals Inc. & 1998 \\
\hline 73 & Finning International Inc. & 1933 \\
\hline 74 & Firan Technology Group Corporation & 1983 \\
\hline 75 & First Quantum Minerals Ltd. & 1983 \\
\hline 76 & Fortis Inc. & 1977 \\
\hline 77 & Gabriel Resources Ltd. & 1986 \\
\hline 78 & Weston (George) Limited & 1928 \\
\hline 79 & Gildan Activewear Inc. & 1984 \\
\hline 80 & Goldcorp Inc. & 1994 \\
\hline 81 & Golden Queen Mining Co. Ltd. & 1985 \\
\hline 82 & Golden Star Resources Ltd. & 1992 \\
\hline 83 & Goodfellow Inc. & 1972 \\
\hline 84 & Hammond Manufacturing Company Limited & 1917 \\
\hline 85 & Helix BioPharma Corp. & 1993 \\
\hline 86 & High Liner Foods Incorporated & 1953 \\
\hline 87 & Husky Energy Inc. & 1979 \\
\hline 88 & Hydrogenics Corporation & 1995 \\
\hline 89 & IAMGold Corporation & 1990 \\
\hline 90 & Imperial Metals Corporation & 1981 \\
\hline 91 & Imperial Oil Limited & 1880 \\
\hline 92 & Inter Pipeline Ltd. & 1997 \\
\hline 93 & Interfor Corporation & 1963 \\
\hline 94 & Intertape Polymer Group Inc. & 1989 \\
\hline 95 & Intrinsyc Technologies Corporation & 1992 \\
\hline 96 & Jean Coutu Group (PJC) Inc. (The) & 1969 \\
\hline 97 & Kinross Gold Corporation & 1993 \\
\hline 98 & Lassonde Industries Inc. & 1981 \\
\hline 99 & Leon's Furniture Limited & 1969 \\
\hline 100 & Linamar Corporation & 1966 \\
\hline 101 & Loblaw Companies Limited & 1956 \\
\hline 102 & Logistec Corporation & 1952 \\
\hline 103 & MacDonald, Dettwiler and Associates Ltd. & 1969 \\
\hline 104 & Magellan Aerospace Corporation & 1996 \\
\hline 105 & Magna International Inc. & 1961 \\
\hline 106 & Maple Leaf Foods Inc. & 1927 \\
\hline
\end{tabular}




\begin{tabular}{|c|c|c|}
\hline S. No. & Company Name & \begin{tabular}{|l|} 
Date of \\
Incorporation
\end{tabular} \\
\hline 107 & Marsulex Inc/Chemtrade Logistics Inc ${ }^{4}$ & 1989 \\
\hline 108 & Martinrea International Inc. & 1987 \\
\hline 109 & McEwen Mining Inc. & 1979 \\
\hline 110 & MDC Partners Inc. & 1980 \\
\hline 111 & Methanex Corporation & 1968 \\
\hline 112 & Metro Inc. & 1982 \\
\hline 113 & Microbix Biosystems Inc. & 1990 \\
\hline 114 & Mountain Province Diamonds Inc. & 1997 \\
\hline 115 & Mullen Group Ltd. & 1993 \\
\hline 116 & Nevsun Resources Ltd. & 1965 \\
\hline 117 & Newalta Corporation & 1993 \\
\hline 118 & Newfoundland Capital Corporation Limited & 1949 \\
\hline 119 & NGEx Resources Inc. & 1983 \\
\hline 120 & Norbord Inc. & 1987 \\
\hline 121 & Norsat International Inc. & 1982 \\
\hline 122 & North American Palladium Ltd. & 1968 \\
\hline 123 & North West Company Inc. & 1997 \\
\hline 124 & Northland Power Inc. & 1997 \\
\hline 125 & Novagold Resources Inc. & 1984 \\
\hline 126 & Novelion Therapeutics Inc. & 1981 \\
\hline 127 & Nuvo Pharmaceuticals Inc. & 1983 \\
\hline 128 & NXT Energy Solutions Inc. & 1994 \\
\hline 129 & Obsidian Energy Ltd. & 1979 \\
\hline 130 & Oncolytics Biotech Inc. & 1998 \\
\hline 131 & Open Text Corporation & 1991 \\
\hline 132 & Orvana Minerals Corp. & 1987 \\
\hline 133 & Pacific Insight Electronics Corp. & 1979 \\
\hline 134 & Pan American Silver Corp. & 1979 \\
\hline 135 & Paramount Resources Ltd. & 1978 \\
\hline 136 & Parkland Fuel Corporation & 1977 \\
\hline 137 & Pason Systems Inc. & 1996 \\
\hline 138 & Pembina Pipeline Corporation & 1997 \\
\hline 139 & Pengrowth Energy Corporation & 1988 \\
\hline
\end{tabular}

\footnotetext{
${ }^{4}$ Backfill filling was performed by Compustat - Capital IQ for Chemtrade Logistic Inc. Marsulex Inc launched
} Chemtrade's IPO in 2001; prior statements of Marsulex were used as backfilling for Chemtrade Logistic Inc. 


\begin{tabular}{|c|c|c|}
\hline S. No. & Company Name & \begin{tabular}{|l|} 
Date of \\
Incorporation
\end{tabular} \\
\hline 140 & Peyto Exploration \& Development Corp. & 1997 \\
\hline 141 & Potash Corporation of Saskatchewan Inc. & 1975 \\
\hline 142 & \begin{tabular}{|l|} 
Precision Drilling Corporation \\
\end{tabular} & 1969 \\
\hline 143 & Premium Brands Holdings Corporation & 1917 \\
\hline 144 & ProMetic Life Sciences Inc. & 1994 \\
\hline 145 & Pulse Seismic Inc. & 1985 \\
\hline 146 & Quebecor Inc. & 1965 \\
\hline 147 & Reitmans (Canada) Limited & 1947 \\
\hline 148 & Richelieu Hardware Ltd. & 1968 \\
\hline 149 & Richmont Mines Inc. & 1981 \\
\hline 150 & Ritchie Bros. Auctioneers Incorporated & 1958 \\
\hline 151 & RMP Energy Inc. & 1987 \\
\hline 152 & Rogers Communications Inc. & 1920 \\
\hline 153 & Rogers Sugar Inc. & 1997 \\
\hline 154 & Russel Metals Inc. & 1929 \\
\hline 155 & Saputo Inc. & 1992 \\
\hline 156 & Shaw Communications Inc. & 1966 \\
\hline 157 & ShawCor Ltd. & 1968 \\
\hline 158 & Sherritt International Corporation & 1995 \\
\hline 159 & Silver Standard Resources Inc. & 1946 \\
\hline 160 & SNC-Lavalin Group Inc. & 1967 \\
\hline 161 & Spectral Medical Inc. & 1991 \\
\hline 162 & Stantec Inc. & 1954 \\
\hline 163 & Strongco Corporation & 1995 \\
\hline 164 & Stuart Olson Inc. & 1981 \\
\hline 165 & Suncor Energy Inc. & 1979 \\
\hline 166 & SunOpta Inc. & 1973 \\
\hline 167 & Tanzanian Royalty Exploration Corporation & 1990 \\
\hline 168 & Taseko Mines Limited & 1966 \\
\hline 169 & Teck Resources Limited & 1963 \\
\hline 170 & Telesta Therapeutics Inc. & 1979 \\
\hline 171 & TELUS Corporation & 1998 \\
\hline 172 & Tembec Inc. & 1973 \\
\hline 173 & Tesco Corp. & 1993 \\
\hline 174 & Theratechnologies Inc. & 1993 \\
\hline 175 & Thomson Reuters Corporation & 1977 \\
\hline
\end{tabular}




\begin{tabular}{|c|c|c|}
\hline S. No. & Company Name & $\begin{array}{l}\text { Date of } \\
\text { Incorporation }\end{array}$ \\
\hline 176 & Toromont Industries Ltd. & 1961 \\
\hline 177 & Torstar Corporation & 1967 \\
\hline 178 & Total Energy Services Inc. & 1996 \\
\hline 179 & Touchstone Exploration Inc. & 1983 \\
\hline 180 & TransAlta Corporation & 1985 \\
\hline 181 & Transat A.T. Inc. & 1987 \\
\hline 182 & TransCanada Corporation & 1951 \\
\hline 183 & Transcontinental Inc. & 1978 \\
\hline 184 & TransGlobe Energy Corporation & 1968 \\
\hline 185 & Trican Well Service Ltd. & 1979 \\
\hline 186 & Trinidad Drilling Ltd. & 1996 \\
\hline 187 & Turbo Power System Inc. & 1987 \\
\hline 188 & Turquoise Hill Resources Ltd. & 1994 \\
\hline 189 & TVA Group Inc. & 1960 \\
\hline 190 & TWC Enterprises Limited & 1997 \\
\hline 191 & Uni-Select Inc. & 1968 \\
\hline 192 & Uranium One Inc. & 1997 \\
\hline 193 & Valeant Pharmaceuticals International Inc. & 1987 \\
\hline 194 & Valener Inc. & 1987 \\
\hline 195 & Velan Inc. & 1952 \\
\hline 196 & Veresen Inc. & 1997 \\
\hline 197 & Vermilion Energy Inc. & 1994 \\
\hline 198 & Vista Gold Corp. & 1983 \\
\hline 199 & Wajax Corporation & 1910 \\
\hline 200 & Waste Connections, Inc. & 1997 \\
\hline 201 & West Fraser Timber Co. Ltd. & 1966 \\
\hline 202 & Western Forest Products Inc. & 1955 \\
\hline 203 & WestJet Airlines Ltd. & 1994 \\
\hline 204 & Westport Fuel Systems Inc. & 1995 \\
\hline 205 & Winpak Ltd. & 1975 \\
\hline 206 & Yorbeau Resources Inc. & 1984 \\
\hline 207 & Zargon Oil \& Gas Ltd. & 1987 \\
\hline 208 & ZCL Composites Inc. & 1987 \\
\hline
\end{tabular}




\section{Appendix B: SAS Codes and Results}

Panel data analysis was carried out using SAS 9.4 Virtual Application, licensed to

Ryerson University. Below are the SAS statements that were used to perform various fixed

effects models and random effects models analyses, followed by SAS results.

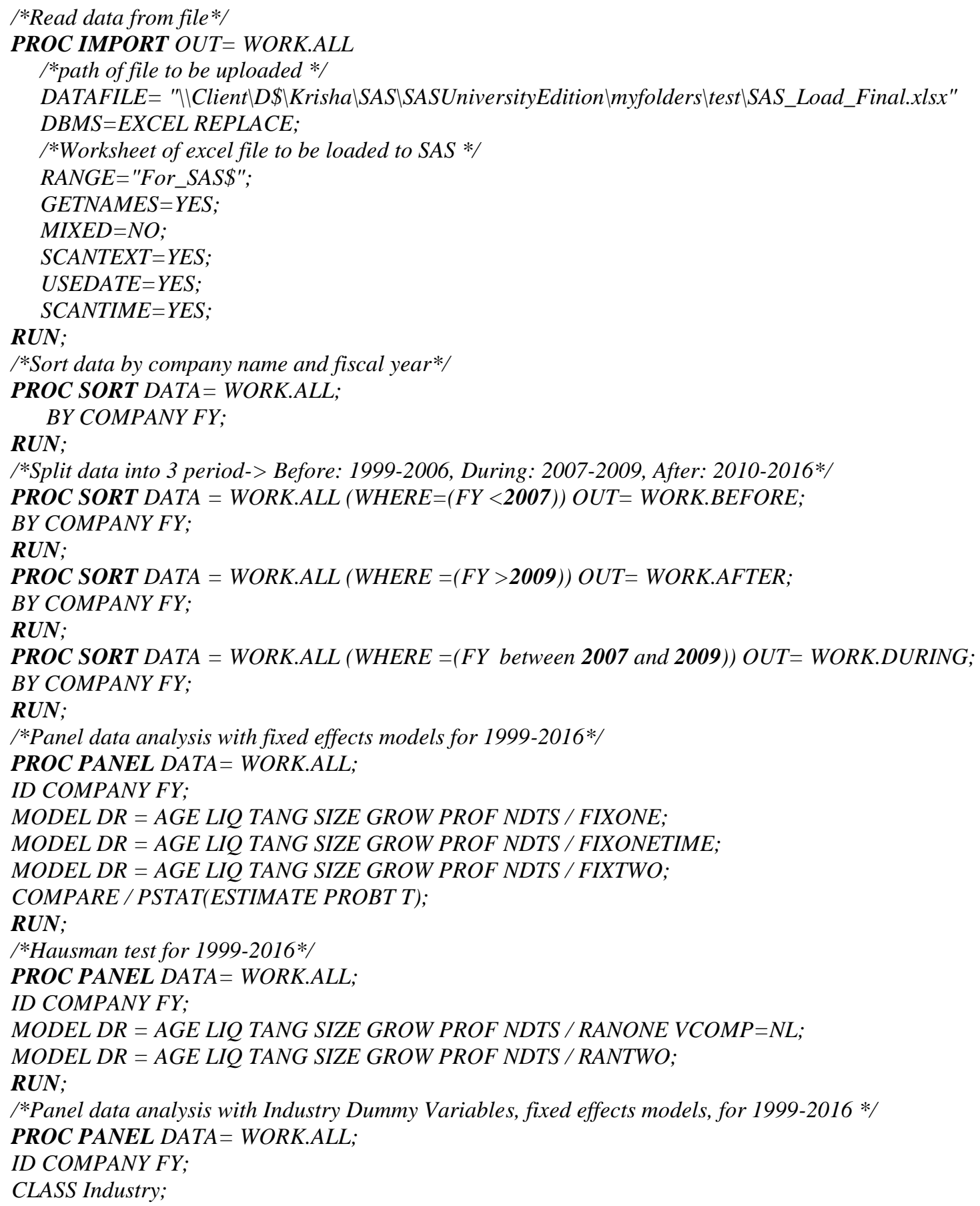


MODEL DR = AGE LIQ TANG SIZE GROW PROF NDTS Industry / FIXONE;

MODEL DR = AGE LIQ TANG SIZE GROW PROF NDTS Industry / FIXONETIME;

MODEL DR = AGE LIQ TANG SIZE GROW PROF NDTS Industry / FIXTWO;

COMPARE / PSTAT(ESTIMATE PROBT T);

$R U N$;

/*Hausman test with Industry Dummy Variables for 1999-2016, */

PROC PANEL DATA = WORK.ALL;

ID COMPANY FY;

CLASS Industry;

MODEL DR = AGE LIQ TANG SIZE GROW PROF NDTS Industry $/$ RANONE VCOMP $=N L$;

MODEL DR = AGE LIQ TANG SIZE GROW PROF NDTS Industry / RANTWO;

RUN;

I* Panel data analysis using one-way fixed effects model+ Hausman test for 1999-2006*/

PROC PANEL DATA = WORK.BEFORE;

ID COMPANY FY;

MODEL DR = AGE LIQ TANG SIZE GROW PROF NDTS / FIXONE;

MODEL DR = AGE LIQ TANG SIZE GROW PROF NDTS $/$ RANONE VCOMP $=N L$;

RUN;

/* Panel data analysis using fixed effects models for 2007-2009*/

PROC PANEL DATA = WORK.DURING;

ID COMPANY FY;

MODEL DR = AGE LIQ TANG SIZE GROW PROF NDTS / FIXONE;

MODEL DR = AGE LIQ TANG SIZE GROW PROF NDTS / FIXONETIME;

MODEL DR = AGE LIQ TANG SIZE GROW PROF NDTS / FIXTWO;

COMPARE / PSTAT(ESTIMATE PROBT T);

RUN;

/* Hausman test for 2007-2009*/

PROC PANEL DATA= WORK.DURING;

ID COMPANY FY;

MODEL DR = AGE LIQ TANG SIZE GROW PROF NDTS / RANONE VCOMP $=N L$;

MODEL DR = AGE LIQ TANG SIZE GROW PROF NDTS / RANTWO;

RUN;

I*Panel data analysis with Industry Dummy Variables, fixed effects models, for 2007-2009*/

PROC PANEL DATA = WORK.DURING;

ID COMPANY FY;

CLASS Industry;

MODEL DR = AGE LIQ TANG SIZE GROW PROF NDTS Industry / FIXONE;

MODEL DR = AGE LIQ TANG SIZE GROW PROF NDTS Industry / FIXONETIME;

MODEL DR = AGE LIQ TANG SIZE GROW PROF NDTS Industry / FIXTWO;

COMPARE / PSTAT(ESTIMATE PROBT T);

RUN;

/* Hausman test with Industry Dummy Variables for 2007-2009*/

PROC PANEL DATA= WORK.DURING;

ID COMPANY FY;

CLASS Industry;

MODEL DR = AGE LIQ TANG SIZE GROW PROF NDTS Industry/ RANONE VCOMP =NL;

MODEL DR = AGE LIQ TANG SIZE GROW PROF NDTS Industry/ RANTWO;

RUN;

/* Panel data analysis using one-way fixed effects model+ Hausman test for 2010-2016*/

PROC PANEL DATA = WORK.AFTER;

ID COMPANY FY;

MODEL DR = AGE LIQ TANG SIZE GROW PROF NDTS / FIXONE;

MODEL DR = AGE LIQ TANG SIZE GROW PROF NDTS $/$ RANONE VCOMP $=N L$;

RUN;

/*Panel data analysis for Robustness Check*/ 
/*Remove companies in Group $2 * /$

PROC SORT DATA $=$ WORK.ALL $(W H E R E=(R O B U<>2))$ OUT $=$ WORK.ALL_R2;

$B Y$ COMPANY FY;

$\boldsymbol{R U N}$;

/*Panel data analysis with one-way fixed effects models for 1999-2016 after removing Group 2*/

PROC PANEL DATA = WORK.ALL_R2;

ID COMPANY FY;

MODEL DR = AGE LIQ TANG SIZE GROW PROF NDTS / FIXONE;

MODEL DR = AGE LIQ TANG SIZE GROW PROF NDTS / RANONE VCOMP=NL;

COMPARE / PSTAT(ESTIMATE PROBT T);

RUN; 


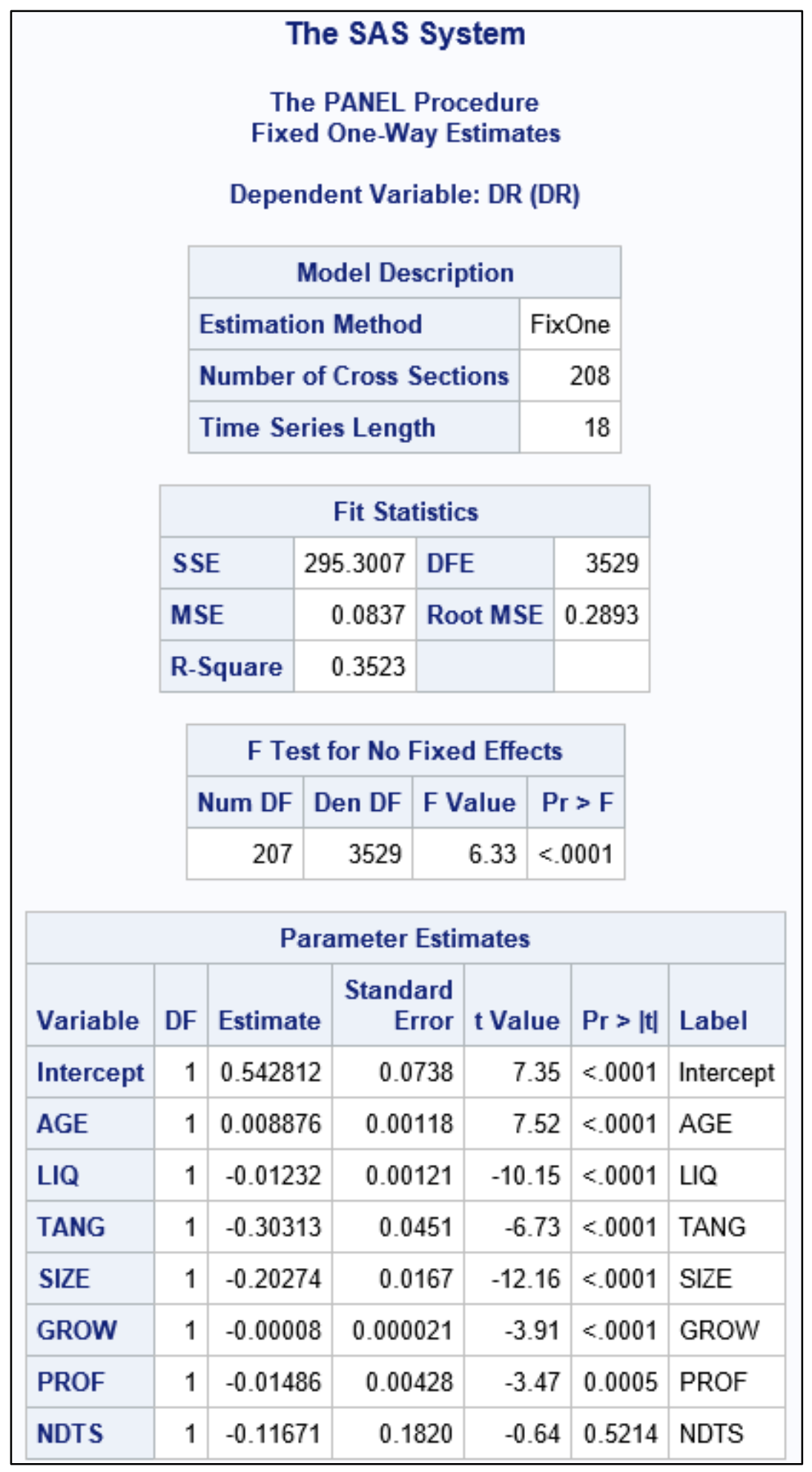

Figure 2: Results of one-way fixed effects model for 1999 to 2016 


\begin{tabular}{|c|c|c|c|c|c|c|c|c|}
\hline & & & he SAS & Sys & stem & & & \\
\hline & & $\begin{array}{r}\text { The } \\
\text { Fixed }\end{array}$ & $\begin{array}{l}\text { PANEL } \\
\text { d One-W }\end{array}$ & $\begin{array}{l}\text { Proc } \\
\text { ay } E\end{array}$ & $\begin{array}{l}\text { cedur } \\
\text { stima }\end{array}$ & $\begin{array}{l}\text { re } \\
\text { ates }\end{array}$ & & \\
\hline & & Depend & dent Var & iable & e: DR & (DR) & & \\
\hline & & & Model De & scrip & tion & & & \\
\hline & & Estimation & netho & & & FixC & One & \\
\hline & & Number o & of Cross & Sect & ions & & 208 & \\
\hline & & Time Seri & ies Leng & & & & 8 & \\
\hline & & & Fit Sta & tistic & & & & \\
\hline & SS & SE & 172.1448 & DFI & & & 1449 & \\
\hline & MS & SE & 0.1188 & Ro & ot MS & & 0.3447 & \\
\hline & & Square & 0.4098 & & & & & \\
\hline & & F Test & t for No & Fixe & d Effe & ects & & \\
\hline & & Num DF & Den DF & F V & alue & & $r>F$ & \\
\hline & & 207 & 1449 & & 3.86 & & 0001 & \\
\hline & & & rameter & Estir & mates & & & \\
\hline Variable & DF & Estimate & e $\begin{array}{r}\text { Stand } \\
\mathrm{E}\end{array}$ & $\begin{array}{l}\text { ard } \\
\text { rror }\end{array}$ & t Va & alue & $\operatorname{Pr}>|t|$ & Label \\
\hline Intercept & 1 & 0.804993 & 0.1 & 428 & & 5.64 & $<.0001$ & Intercept \\
\hline AGE & 1 & 0.003348 & 0.00 & 448 & & 0.75 & 0.4548 & AGE \\
\hline LIQ & 1 & -0.00852 & 0.00 & 201 & & 4.24 & $<.0001$ & LIQ \\
\hline TANG & 1 & -0.50445 & 0.0 & 965 & & 5.23 & $<.0001$ & TANG \\
\hline SIZE & 1 & -0.27989 & 0.0 & 386 & & 7.24 & $<.0001$ & SIZE \\
\hline GROW & 1 & -0.00014 & \begin{tabular}{l|l}
4 & 0.000
\end{tabular} & 028 & & 4.87 & $<.0001$ & GROW \\
\hline PROF & 1 & -0.00514 & 0.00 & 550 & & 0.93 & 0.3505 & PROF \\
\hline NDTS & 1 & -0.33541 & 0.3 & 159 & & 1.06 & 0.2885 & NDTS \\
\hline
\end{tabular}

Figure 3: Results of one-way fixed effects model for 1999 to 2006 


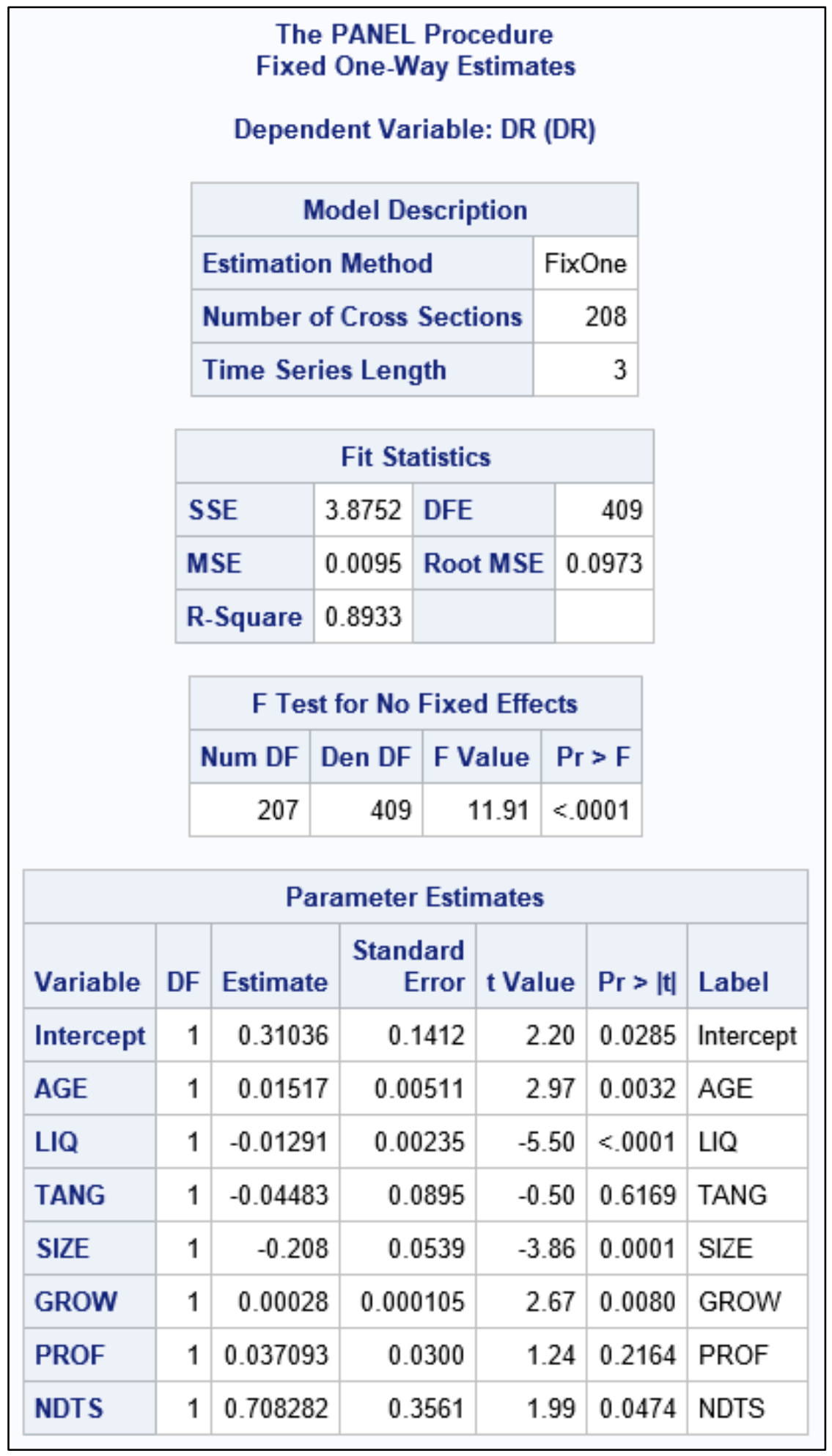

Figure 4: Results of one-way fixed effects model for 2007 to 2009 


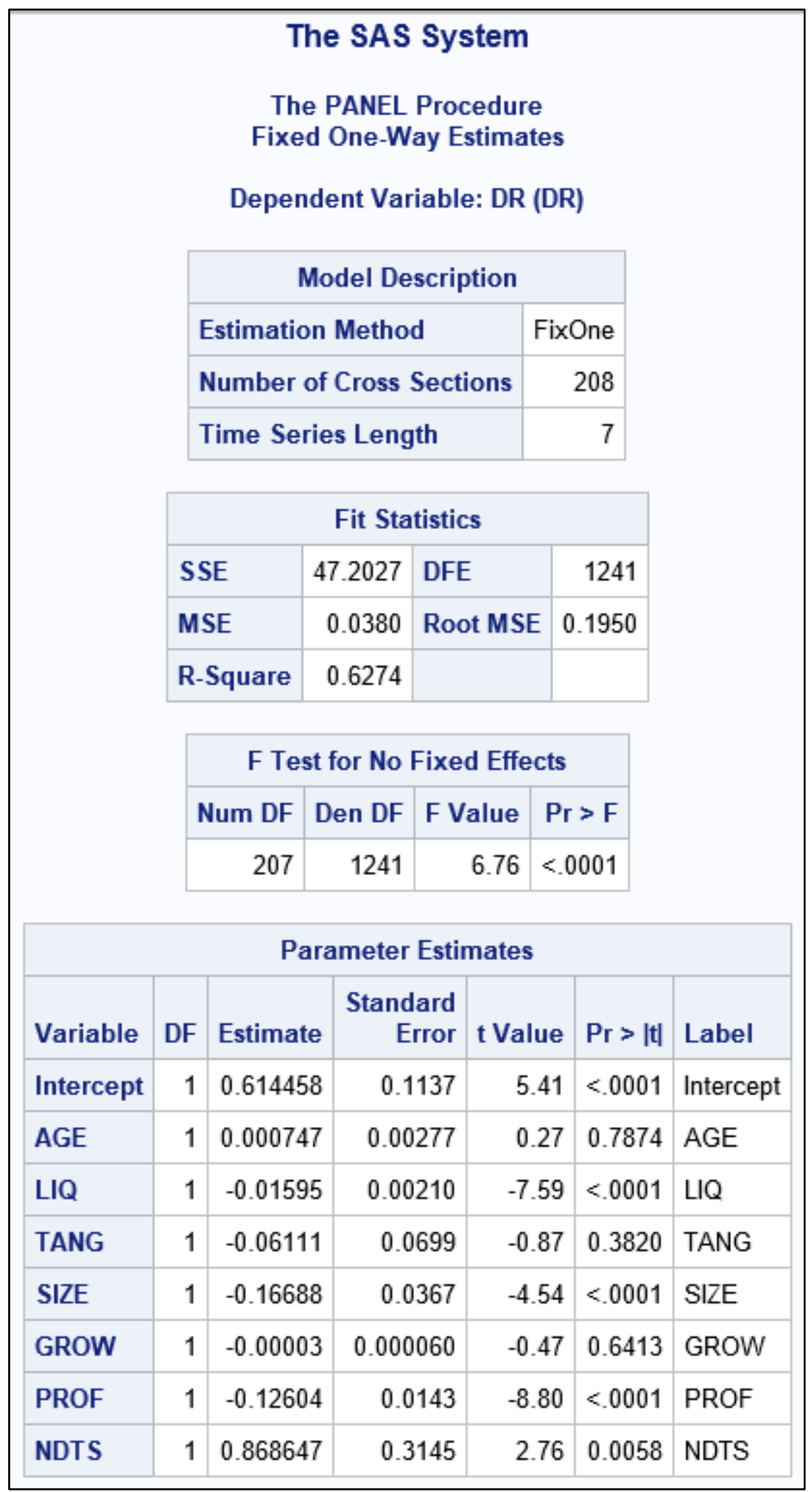

Figure 5: Results of one-way fixed effects model for 2010 to 2016 


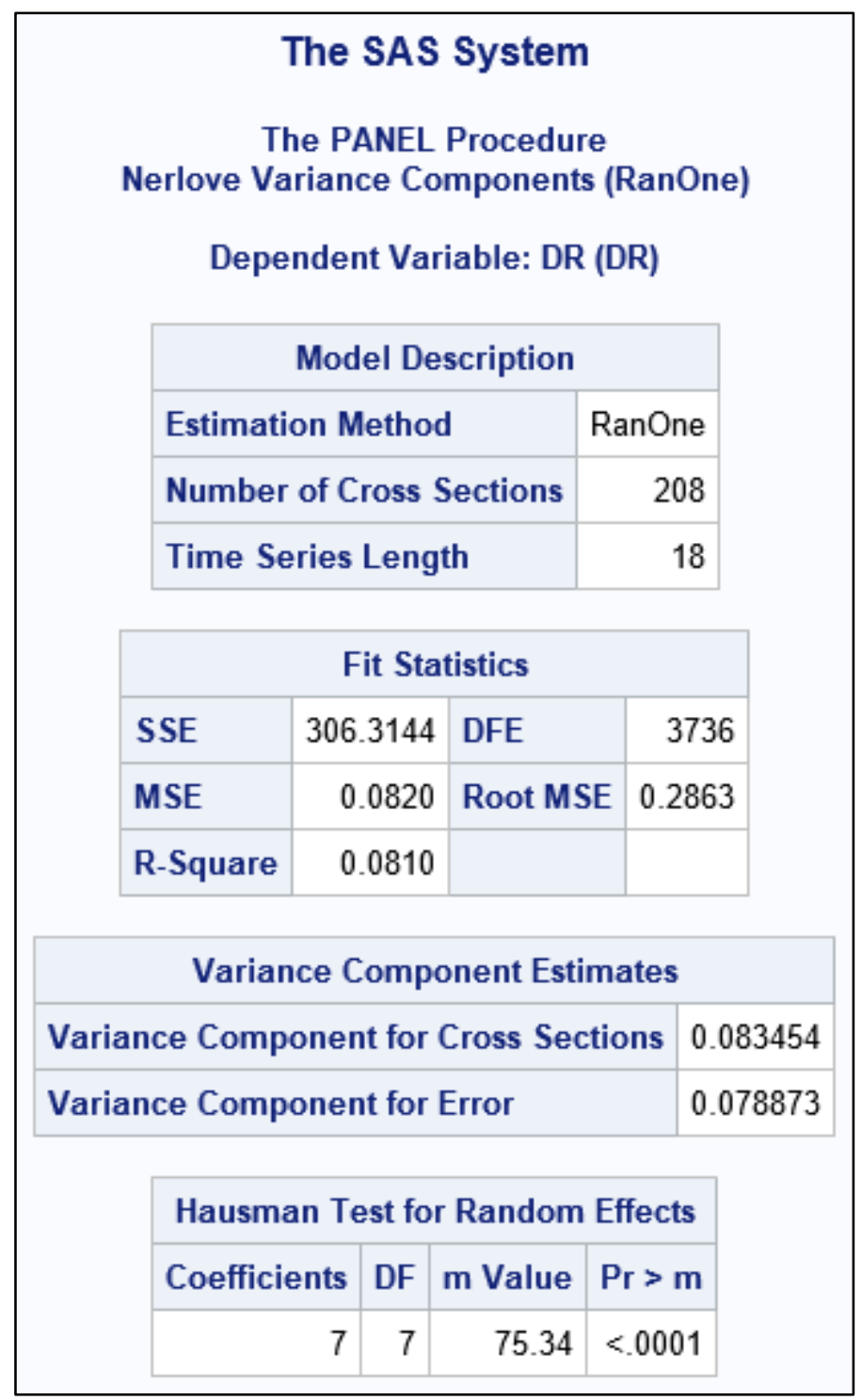

Figure 6: Hausman test results of one-way random effects model for 1999 to 2016 


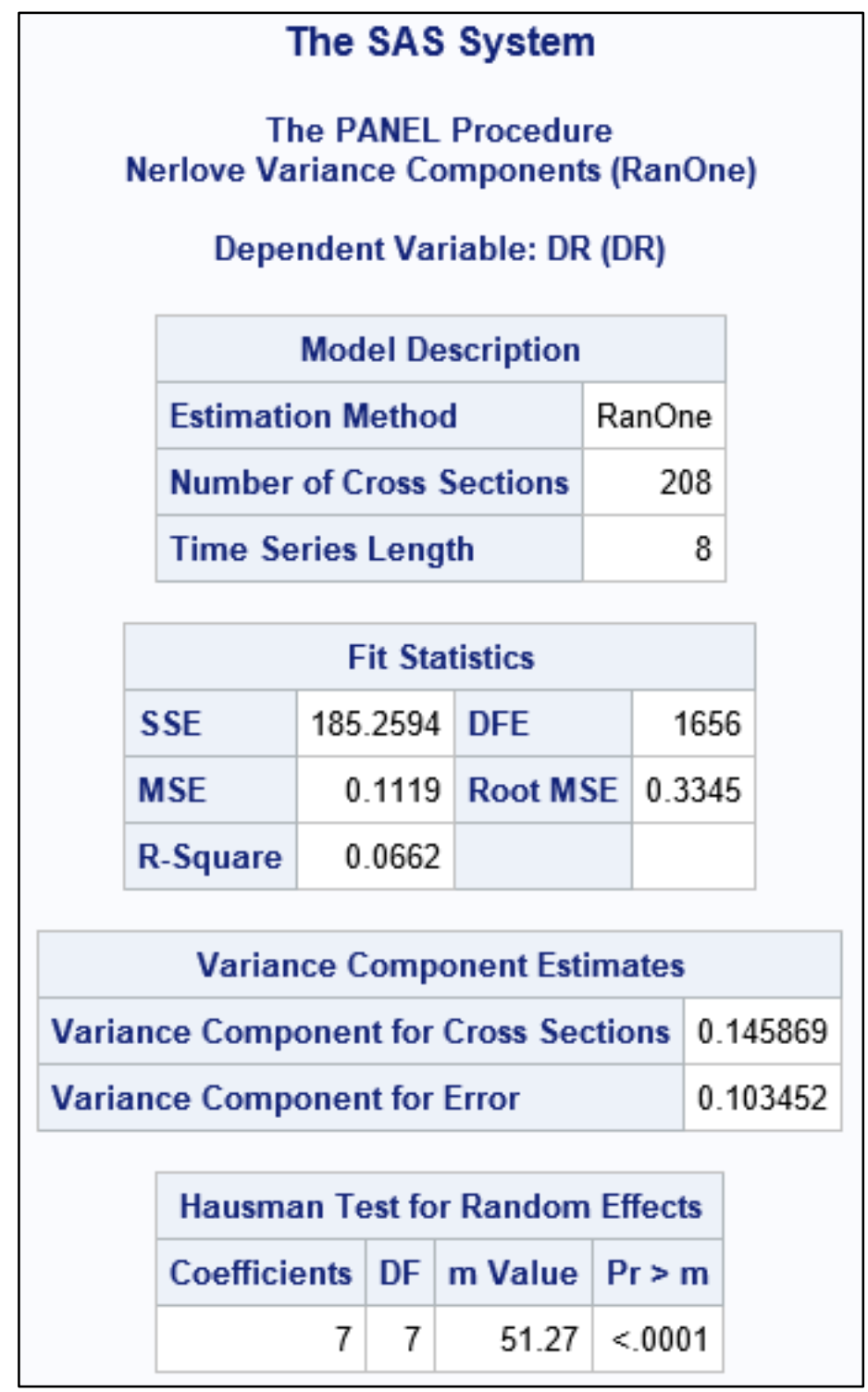

Figure 7: Hausman test results of one-way random effects model for 1999 to 2006 


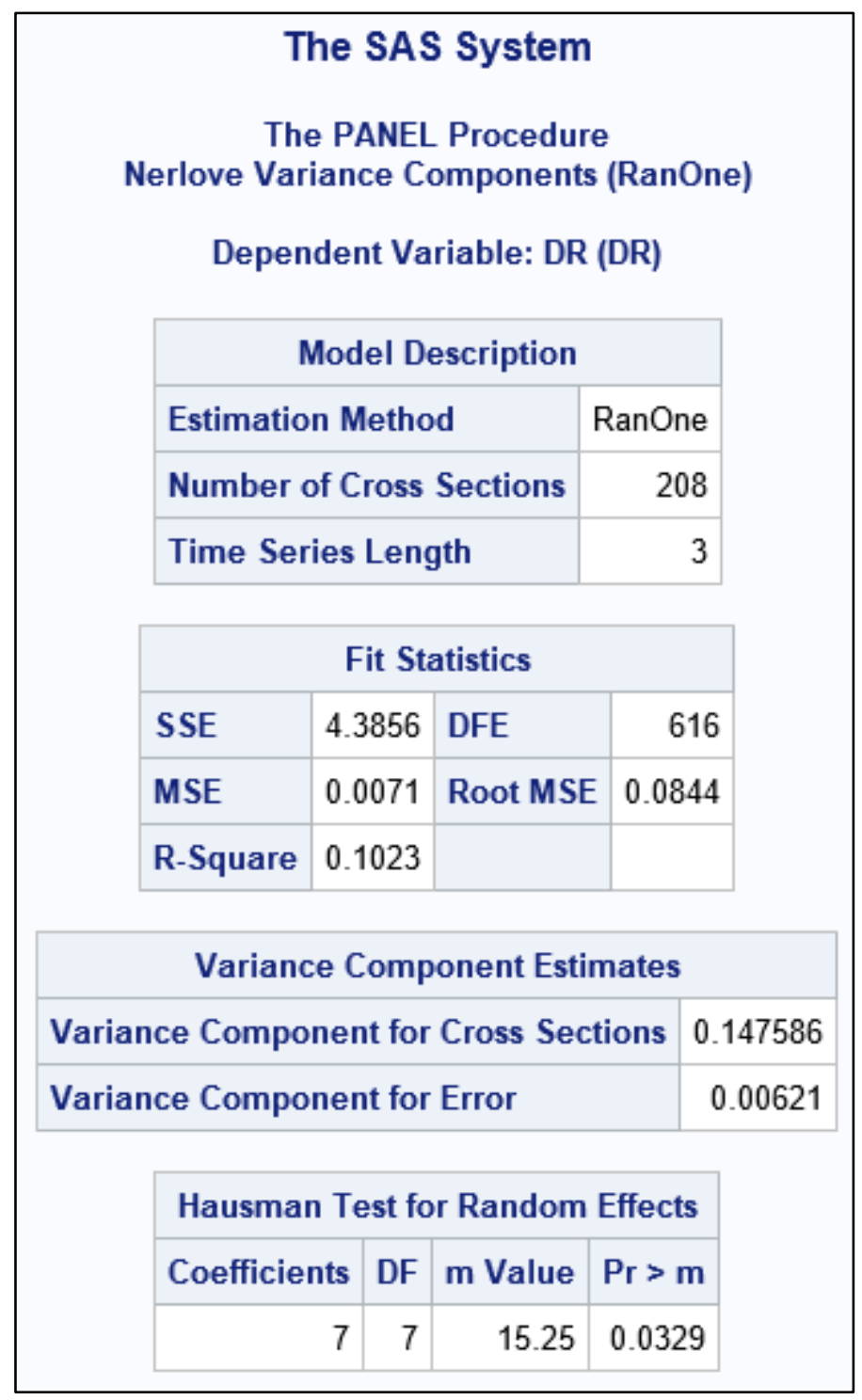

Figure 8: Hausman test results of one-way random effects model for 2007 to 2009 


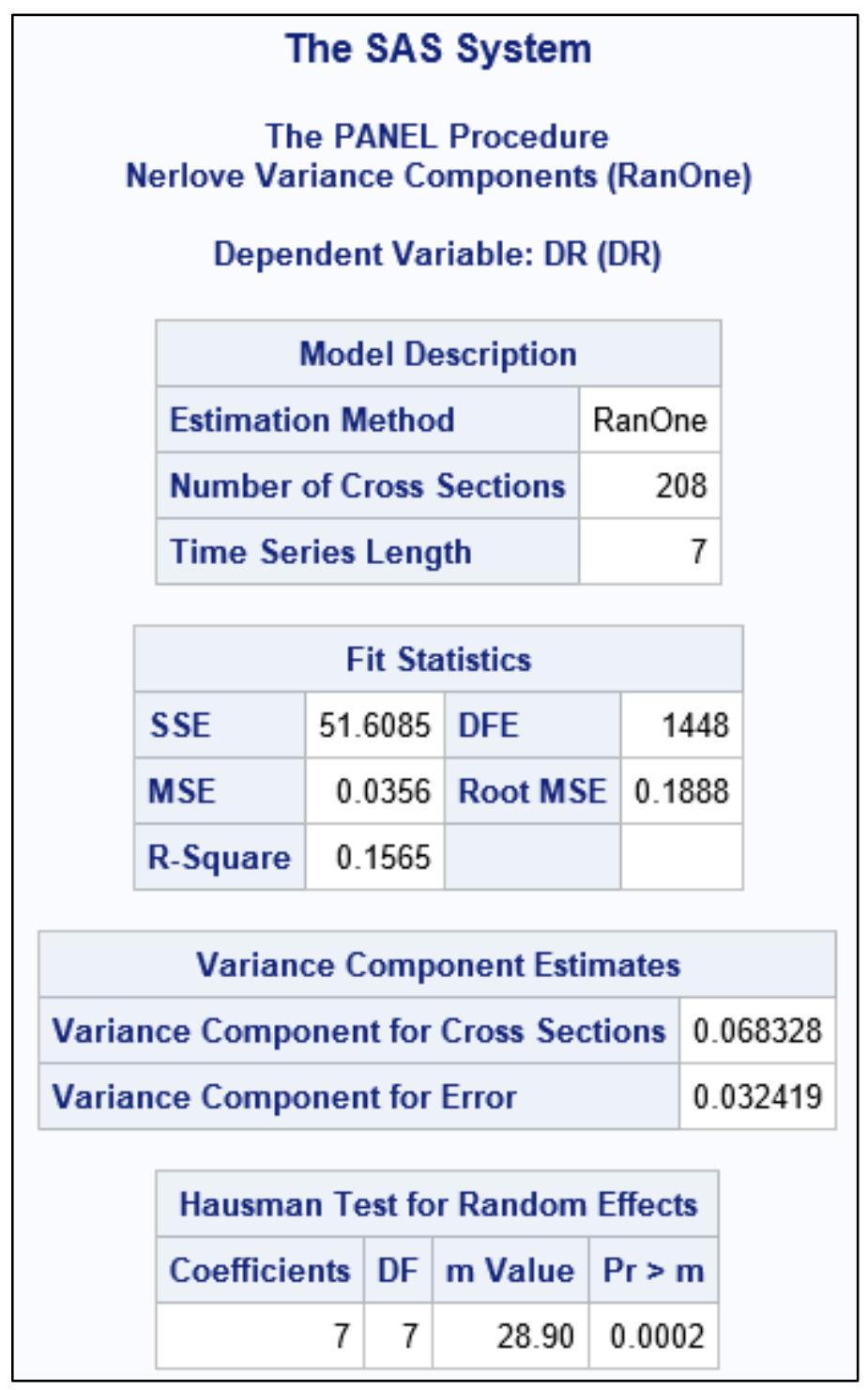

Figure 9: Hausman test results of one-way random effects model for 2010 to 2016 


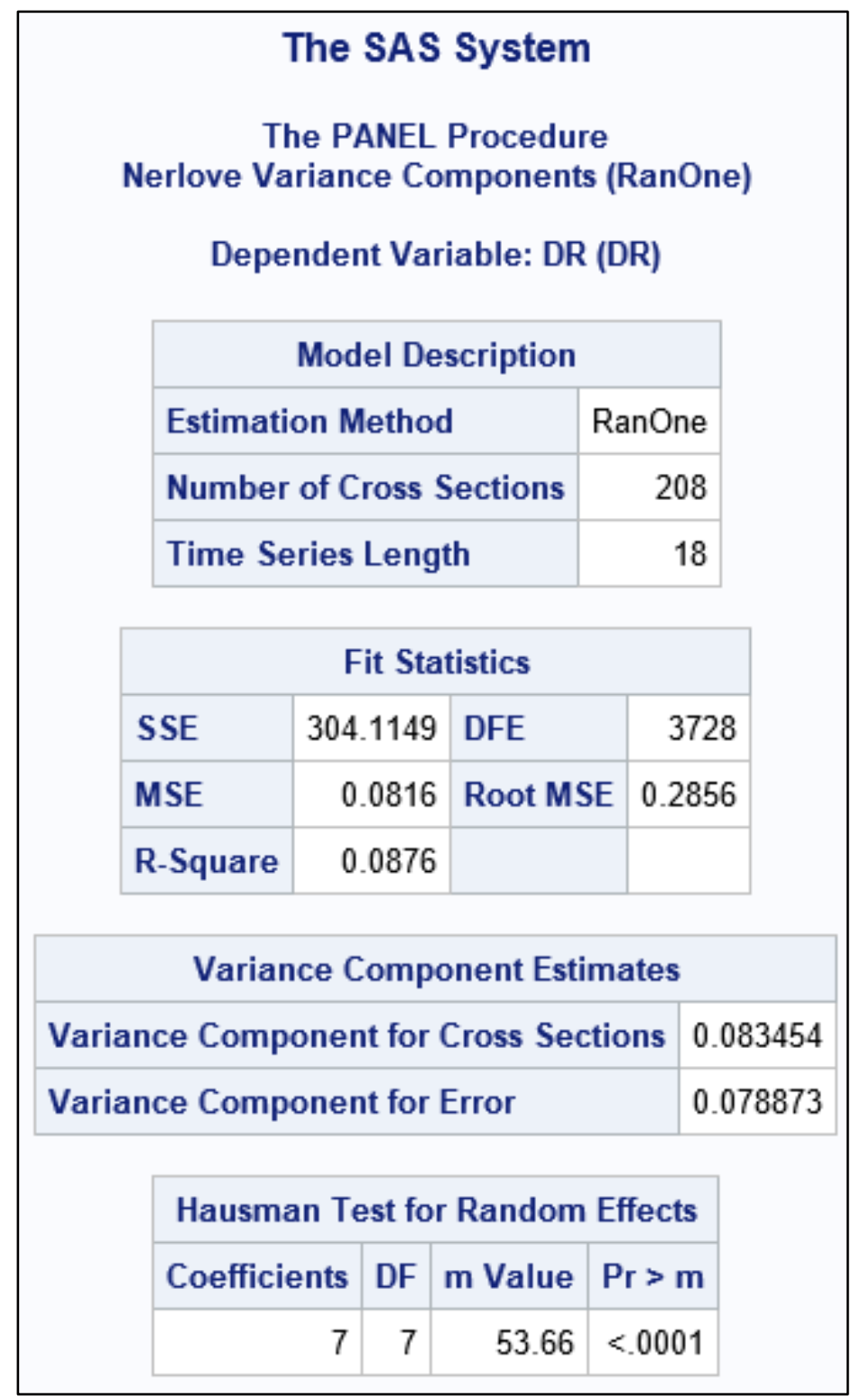

Figure 10: Hausman test results (with Industry Dummy Variables) of one-way random effects model for 1999 to 2016 


The SAS System
The PANEL Procedure
Nerlove Variance Components (RanOne)
Dependent Variable: DR (DR)

Figure 11: Hausman test results (with Industry Dummy Variables) of one-way random effects model for 2007 to 2009 


\begin{tabular}{|c|c|c|c|c|c|c|}
\hline Fuller and Batte & $\begin{array}{l}\text { The } \\
\text { he PA } \\
\text { se Ve }\end{array}$ & $\begin{array}{l}\text { SAS } \\
\text { ANEL } \\
\text { ariano }\end{array}$ & $\begin{array}{l}\text { System } \\
\text { Procedur } \\
\text { ce Compo }\end{array}$ & $\begin{array}{l}\text { re } \\
\text { onents }\end{array}$ & (Rar & nTwo) \\
\hline Depe & nden & t Vari & riable: DR & (DR) & & \\
\hline & Mod & lel Des & escription & & & \\
\hline Estimati & ion $\mathrm{M}$ & lethoc & & RanTv & & \\
\hline Number & of $\mathrm{Cl}$ & ross & Sections & & 08 & \\
\hline Time Se & eries & Leng & & & 18 & \\
\hline & & it Sta & atistics & & & \\
\hline SSE & 320 . & .4569 & DFE & & 3736 & \\
\hline MSE & & .0858 & Root MS & SE 0.2 & 2929 & \\
\hline R-Square & 0 . & .0738 & & & & \\
\hline Variar & ace C & compc & onent Esti & imates & & \\
\hline Variance Comp & onen & t for & Cross Sec & ctions & 0.02 & 25158 \\
\hline Variance Comp & onen & nt for & Time Seri & ies & 0.00 & 0224 \\
\hline Variance Comp & onen & nt for & Error & & 0.08 & 33468 \\
\hline Hausm & an $\mathrm{Te}$ & est for & Random & Effect & & \\
\hline Coeffici & ents & DF & m Value & $\operatorname{Pr}>1$ & & \\
\hline & 6 & 6 & 9.37 & 0.153 & & \\
\hline
\end{tabular}

Figure 12: Hausman test results of two-way random effects model for 1999 to 2016 


\begin{tabular}{|l} 
The SAS System \\
The PANEL Procedure \\
Fuller and Battese Variance Components (Ran Two) \\
Dependent Variable: DR (DR)
\end{tabular}

Figure 13: Hausman test results of two-way random effects model for 2007 to 2009 


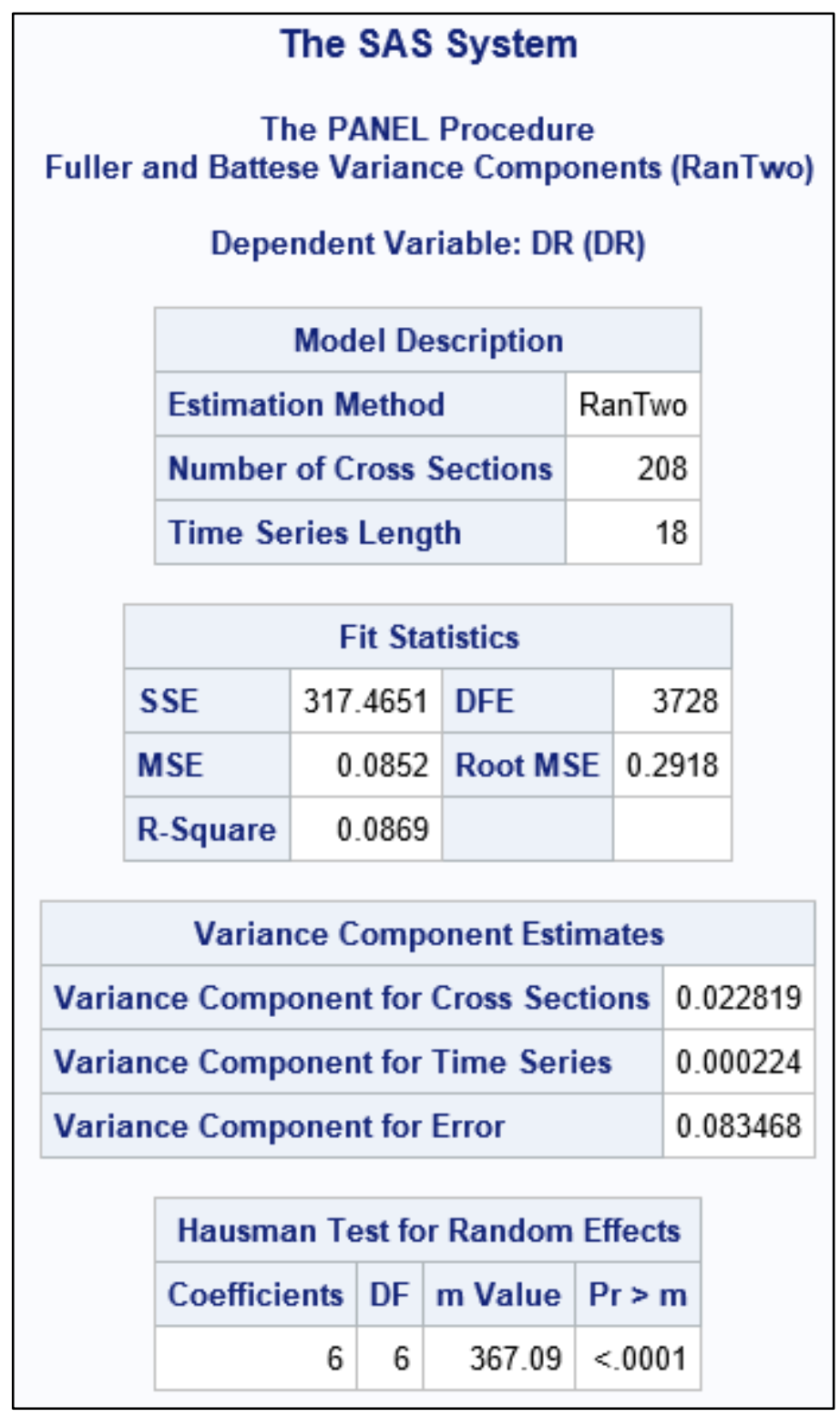

Figure 14: Hausman test results (with Industry Dummy Variables) of two-way random effects model for 1999 to 2016 


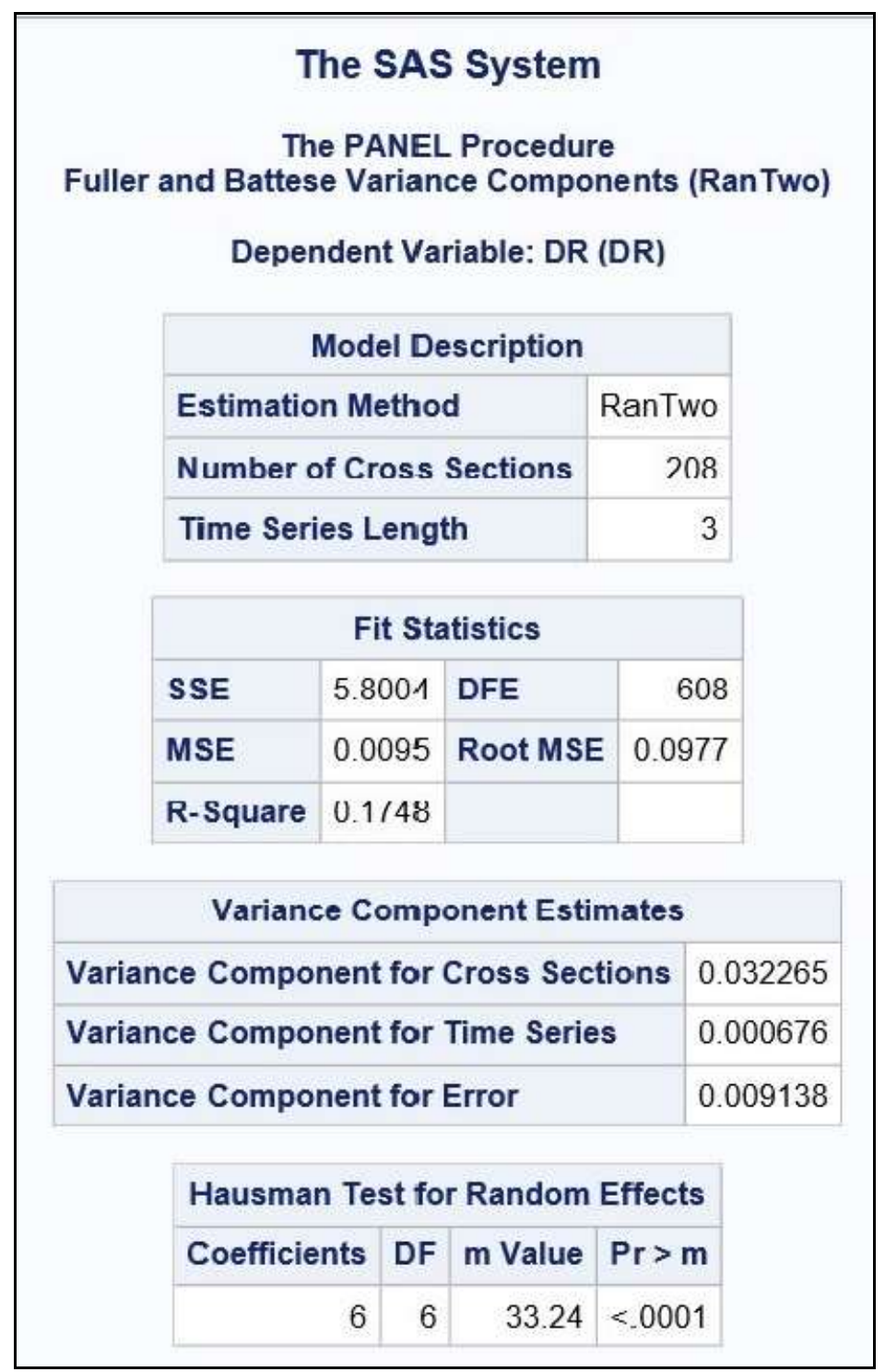

Figure 15: Hausman test results (with Industry Dummy Variables) of two-way random effects model for 2007 to 2009 


\begin{tabular}{|c|c|c|c|c|}
\hline \multicolumn{5}{|c|}{$\begin{array}{l}\text { The PANEL Procedure } \\
\text { Model Comparison } \\
\text { Dependent Variable: DR (DR) }\end{array}$} \\
\hline \multicolumn{5}{|c|}{ Comparison of Model Statistics } \\
\hline \multicolumn{2}{|c|}{ Statistic } & $\begin{array}{r}\text { Model } 1 \\
\text { FixOne }\end{array}$ & $\begin{array}{r}\text { Model } 2 \\
\text { FixOneTm }\end{array}$ & $\begin{array}{c}\text { Model } 3 \\
\text { FixTwo }\end{array}$ \\
\hline \multicolumn{2}{|c|}{ Cross Sections } & 208 & 208 & 208 \\
\hline \multicolumn{2}{|c|}{ Time Series Length } & ength & 18 & 18 \\
\hline \multicolumn{2}{|c|}{ MSE } & 0.0837 & 0.1082 & 0.0835 \\
\hline \multicolumn{2}{|c|}{ Root MSE } & 0.2893 & 0.3290 & 0.2889 \\
\hline \multicolumn{2}{|c|}{ R-Square } & 0.3523 & 0.1172 & 0.3568 \\
\hline \multicolumn{5}{|c|}{ Comparison of Model Parameter Estimates } \\
\hline Variable & & $\begin{array}{c}\text { Model } 1 \\
\text { Fix One }\end{array}$ & $\begin{array}{r}\text { Model } 2 \\
\text { FixOneTm }\end{array}$ & $\begin{array}{r}\text { Model } 3 \\
\text { FixTwo }\end{array}$ \\
\hline In tercept & $\begin{array}{l}\text { Estimate } \\
\mathrm{t} \text { Value } \\
\mathrm{Pr}>|\mathrm{t}|\end{array}$ & $\begin{array}{r}0.542812 \\
7.35 \\
<.0001\end{array}$ & $\begin{array}{r}0.518928 \\
16.68 \\
<.0001\end{array}$ & $\begin{array}{r}0.787697 \\
9.92 \\
<.0001\end{array}$ \\
\hline AGE & $\begin{array}{l}\text { Estimate } \\
\mathrm{t} \text { Value } \\
\mathrm{Pr}>|\mathrm{t}|\end{array}$ & $\begin{array}{r}0.008876 \\
7.52 \\
<.0001\end{array}$ & $\begin{array}{r}0.001172 \\
4.62 \\
<.0001\end{array}$ & $\begin{array}{l}0 \\
. \\
.\end{array}$ \\
\hline LIQ & $\begin{array}{l}\text { Estimate } \\
\mathrm{t} \text { Value } \\
\mathrm{Pr}>|\mathrm{t}|\end{array}$ & $\begin{array}{r}-0.012316 \\
-10.15 \\
<.0001\end{array}$ & $\begin{array}{r}-0.019249 \\
-17.02 \\
<.0001\end{array}$ & $\begin{array}{r}-0.012339 \\
-10.15 \\
<.0001\end{array}$ \\
\hline TANG & $\begin{array}{l}\text { Estimate } \\
\mathrm{t} \text { Value } \\
\mathrm{Pr}>|\mathrm{t}|\end{array}$ & $\begin{array}{r}-0.303127 \\
-6.73 \\
<.0001\end{array}$ & $\begin{array}{r}-0.224703 \\
-10.94 \\
<.0001\end{array}$ & $\begin{array}{r}-0.311255 \\
-6.87 \\
<.0001\end{array}$ \\
\hline SIZE & $\begin{array}{l}\text { Estimate } \\
\mathrm{t} \text { Value } \\
\mathrm{Pr}>|\mathrm{t}|\end{array}$ & $\begin{array}{r}-0.202735 \\
-12.16 \\
<.0001\end{array}$ & $\begin{array}{r}0.006226 \\
0.94 \\
0.3471\end{array}$ & $\begin{array}{r}-0.201166 \\
-11.92 \\
<.0001\end{array}$ \\
\hline GROW & $\begin{array}{l}\text { Estimate } \\
\mathrm{t} \text { Value } \\
\mathrm{Pr}>|\mathrm{t}|\end{array}$ & $\begin{array}{r}-0.000083895 \\
-3.91 \\
<.0001\end{array}$ & $\begin{array}{r}-0.000034722 \\
-1.47 \\
0.1409\end{array}$ & $\begin{array}{r}-0.000089672 \\
-4.16 \\
<.0001\end{array}$ \\
\hline PROF & $\begin{array}{l}\text { Estimate } \\
\mathrm{t} \text { Value } \\
\mathrm{Pr}>|\mathrm{t}|\end{array}$ & $\begin{array}{r}-0.014862 \\
-3.47 \\
0.0005\end{array}$ & $\begin{array}{r}-0.022577 \\
-4.85 \\
<.0001\end{array}$ & $\begin{array}{r}-0.013781 \\
-3.21 \\
0.0013\end{array}$ \\
\hline NDTS & $\begin{array}{l}\text { Estimate } \\
\mathrm{t} \text { Value } \\
\mathrm{Pr}>|\mathrm{t}|\end{array}$ & $\begin{array}{r}-0.116712 \\
-0.64 \\
0.5214\end{array}$ & $\begin{array}{r}0.093461 \\
0.65 \\
0.5132\end{array}$ & $\begin{array}{r}-0.081108 \\
-0.45 \\
0.6563\end{array}$ \\
\hline
\end{tabular}

Figure 16: Results of fixed effects models (one-way, one-time, and two-way) for 1999 to 2016 


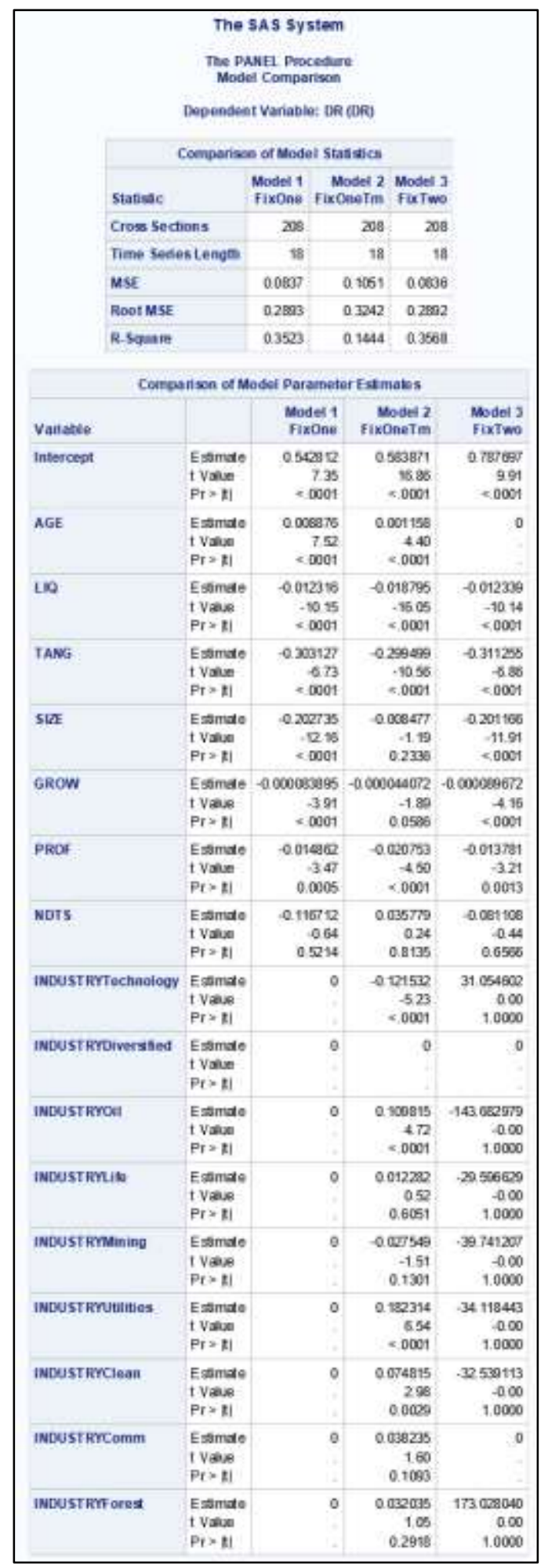

Figure 17: Results of fixed effects models (one-way, one-time, and two-way) with Industry

Dummy Variables for 1999 to 2016 


\begin{tabular}{|c|c|c|c|c|}
\hline \multicolumn{5}{|c|}{ The SAS System } \\
\hline \multirow{2}{*}{\multicolumn{5}{|c|}{$\begin{array}{l}\text { The PANEL Procedure } \\
\text { Model Comparison } \\
\text { Dependent Variable: DR (DR) }\end{array}$}} \\
\hline & & & & \\
\hline \multicolumn{5}{|c|}{ Comparison of Model Statistics } \\
\hline \multicolumn{2}{|l|}{ Statistic } & $\begin{array}{l}\text { Model } 1 \\
\text { FixOne }\end{array}$ & $\begin{array}{r}\text { Model } 2 \\
\text { FixOneTm }\end{array}$ & $\begin{array}{c}\text { Model } 3 \\
\text { FixTwo }\end{array}$ \\
\hline \multicolumn{2}{|c|}{ Cross Sections } & 208 & 208 & 208 \\
\hline \multicolumn{2}{|c|}{ Time Series Length } & 3 & 3 & 3 \\
\hline \multicolumn{2}{|l|}{ MSE } & 0.009475 & 0.0442 & 0.009138 \\
\hline \multicolumn{2}{|c|}{ Root MSE } & 0.0973 & 0.2102 & 0.0956 \\
\hline \multicolumn{2}{|l|}{ R-Square } & 0.8933 & 0.2530 & 0.8974 \\
\hline \multicolumn{5}{|c|}{ Comparison of Model Parameter Estimates } \\
\hline Variable & & $\begin{array}{l}\text { Model } 1 \\
\text { FixOne }\end{array}$ & $\begin{array}{r}\text { Model } 2 \\
\text { FixOneTm }\end{array}$ & $\begin{array}{r}\text { Model } 3 \\
\text { FixTwo }\end{array}$ \\
\hline Intercept & $\begin{array}{l}\text { Estimate } \\
\text { t Value } \\
\mathrm{Pr}>|\mathrm{t}|\end{array}$ & $\begin{array}{r}0.310360 \\
2.20 \\
0.0285\end{array}$ & $\begin{array}{r}0.378519 \\
9.90 \\
<.0001\end{array}$ & $\begin{array}{r}0.682214 \\
5.48 \\
<.0001\end{array}$ \\
\hline AGE & $\begin{array}{l}\text { Estimate } \\
\text { t Value } \\
\mathrm{Pr}>|\mathrm{t}|\end{array}$ & $\begin{array}{r}0.015170 \\
2.97 \\
0.0032\end{array}$ & $\begin{array}{r}0.000793 \\
1.99 \\
0.0470\end{array}$ & $\begin{array}{l}0 \\
.\end{array}$ \\
\hline LIQ & $\begin{array}{l}\text { Estimate } \\
\mathrm{t} \text { Value } \\
\mathrm{Pr}>|\mathrm{t}|\end{array}$ & $\begin{array}{r}-0.012909 \\
-5.50 \\
<.0001\end{array}$ & $\begin{array}{r}-0.016529 \\
-8.61 \\
<.0001\end{array}$ & $\begin{array}{r}-0.012482 \\
-5.41 \\
<.0001\end{array}$ \\
\hline TANG & $\begin{array}{l}\text { Estimate } \\
\mathrm{t} \text { Value } \\
\mathrm{Pr}>|\mathrm{t}|\end{array}$ & $\begin{array}{r}-0.044830 \\
-0.50 \\
0.6169\end{array}$ & $\begin{array}{r}-0.241555 \\
-7.15 \\
<.0001\end{array}$ & $\begin{array}{r}-0.051919 \\
-0.59 \\
0.5553\end{array}$ \\
\hline SIZE & $\begin{array}{l}\text { Estimate } \\
\mathrm{t} \text { Value } \\
\mathrm{Pr}>|\mathrm{t}|\end{array}$ & $\begin{array}{r}-0.208001 \\
-3.86 \\
0.0001\end{array}$ & $\begin{array}{r}0.049608 \\
4.22 \\
<.0001\end{array}$ & $\begin{array}{r}-0.232499 \\
-4.36 \\
<.0001\end{array}$ \\
\hline GROW & $\begin{array}{l}\text { Estimate } \\
\mathrm{t} \text { Value } \\
\mathrm{Pr}>|\mathrm{t}|\end{array}$ & $\begin{array}{r}0.000280 \\
2.67 \\
0.0080\end{array}$ & $\begin{array}{r}-0.000035546 \\
-0.21 \\
0.8375\end{array}$ & $\begin{array}{r}0.000304 \\
2.93 \\
0.0035\end{array}$ \\
\hline PROF & $\begin{array}{l}\text { Estimate } \\
\text { t Value } \\
\mathrm{Pr}>|\mathrm{t}|\end{array}$ & $\begin{array}{r}0.037093 \\
1.24 \\
0.2164\end{array}$ & $\begin{array}{r}-0.196246 \\
-6.52 \\
<.0001\end{array}$ & $\begin{array}{r}0.048514 \\
1.64 \\
0.1015\end{array}$ \\
\hline NDTS & $\begin{array}{l}\text { Estimate } \\
t \text { Value } \\
\mathrm{Pr}>|\mathrm{t}|\end{array}$ & $\begin{array}{r}0.708282 \\
1.99 \\
0.0474\end{array}$ & $\begin{array}{r}0.321052 \\
1.30 \\
0.1934\end{array}$ & $\begin{array}{r}0.694899 \\
1.99 \\
0.0476\end{array}$ \\
\hline
\end{tabular}

Figure 18: Results of fixed effects models (one-way, one-time, and two-way) for 2007 to 2009 


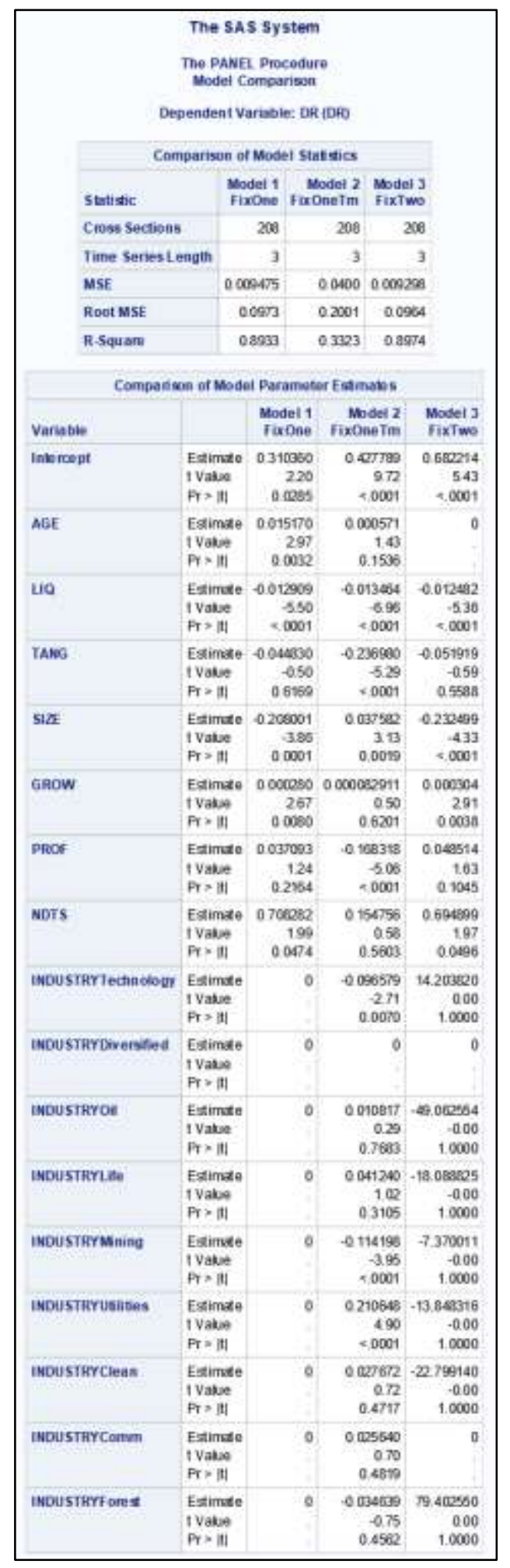

Figure 19: Results of fixed effects models (one-way, one-time, and two-way) with Industry Dummy Variables for 2007 to 2009 


\section{Appendix C: Robustness Test - Grouping of Companies and Results}

\begin{tabular}{|c|c|c|}
\hline S. No. & Company Name & Group \\
\hline 1 & Absolute Software Corporation & 1 \\
\hline 2 & ADF Group Inc. & 2 \\
\hline 3 & Advantage Oil \& Gas Ltd. & 3 \\
\hline 4 & Aecon Group Inc. & 4 \\
\hline 5 & AEterna Zentaris Inc. & 5 \\
\hline 6 & AgJunction Inc. & 1 \\
\hline 7 & Agnico Eagle Mines Limited & 2 \\
\hline 8 & Agrium Inc. & 3 \\
\hline 9 & AirBoss of America Corp. & 4 \\
\hline 10 & Akita Drilling Ltd. & 5 \\
\hline 11 & Alamos Gold Inc. & 1 \\
\hline 12 & Algoma Central Corporation & 2 \\
\hline 13 & Almaden Minerals Ltd. & 3 \\
\hline 14 & AltaGas Ltd. & 4 \\
\hline 15 & Aptose Biosciences Inc. & 5 \\
\hline 16 & Aralez Pharmaceuticals Inc. & 1 \\
\hline 17 & ARC Resources Ltd. & 2 \\
\hline 18 & Atco Ltd. & 3 \\
\hline 19 & Aurinia Pharmaceuticals Inc. & 4 \\
\hline 20 & Badger Daylighting Ltd. & 5 \\
\hline 21 & Ballard Power Systems Inc. & 1 \\
\hline 22 & Barrick Gold Corporation & 2 \\
\hline 23 & Baytex Energy Corp. & 3 \\
\hline 24 & BCE Inc. & 4 \\
\hline 25 & BELLUS Health Inc. & 5 \\
\hline 26 & Big Rock Brewery Inc. & 1 \\
\hline 27 & Bird Construction Inc. & 2 \\
\hline 28 & BlackBerry Limited & 3 \\
\hline 29 & BMTC Group Inc. & 4 \\
\hline 30 & Bombardier Inc. & 5 \\
\hline 31 & Bonavista Energy Corporation & 1 \\
\hline 32 & Bonterra Energy Corp. & 2 \\
\hline 33 & Boralex Inc. & 3 \\
\hline 34 & Boyd Group Services Inc. & 4 \\
\hline 35 & Brampton Brick Limited & 5 \\
\hline 36 & Brick Brewing Co. Limited & 1 \\
\hline 37 & Buhler Industries Inc. & 2 \\
\hline 38 & Caldwell Partners International Inc. (The) & 3 \\
\hline
\end{tabular}




\begin{tabular}{|c|c|c|}
\hline S. No. & Company Name & Group \\
\hline 39 & Calfrac Well Services Ltd. & 4 \\
\hline 40 & Calian Group Ltd. & 5 \\
\hline 41 & Cameco Corporation & 1 \\
\hline 42 & Canadian National Railway Company & 2 \\
\hline 43 & Canadian Natural Resources Limited & 3 \\
\hline 44 & Canadian Pacific Railway Limited & 4 \\
\hline 45 & Canadian Tire Corporation Limited & 5 \\
\hline 46 & Canam Group Inc. & 1 \\
\hline 47 & Canfor Corporation & 2 \\
\hline 48 & Cardiome Pharma Corp. & 3 \\
\hline 49 & Cascades Inc. & 4 \\
\hline 50 & Cathedral Energy Services Ltd. & 5 \\
\hline 51 & CCL Industries Inc. & 1 \\
\hline 52 & Celestica Inc. & 2 \\
\hline 53 & CGI Group Inc. & 3 \\
\hline 54 & Cogeco Communications Inc. & 4 \\
\hline 55 & Cogeco Inc.-SUB VTG & 5 \\
\hline 56 & Computer Modelling Group Ltd. & 1 \\
\hline 57 & Corby Spirit and Wine Limited & 2 \\
\hline 58 & Corus Entertainment Inc. & 3 \\
\hline 59 & Cott Corporation & 4 \\
\hline 60 & Descartes Systems Group Inc. (The) & 5 \\
\hline 61 & Dominion Diamond Corporation & 1 \\
\hline 62 & Dorel Industries Inc. & 2 \\
\hline 63 & Dundee Precious Metals Inc. & 3 \\
\hline 64 & Electrovaya Inc. & 4 \\
\hline 65 & Emera Incorporated & 5 \\
\hline 66 & Enbridge Inc. & 1 \\
\hline 67 & Encana Corporation & 2 \\
\hline 68 & Enghouse Systems Limited & 3 \\
\hline 69 & Ensign Energy Services Inc. & 4 \\
\hline 70 & Exco Technologies Limited & 5 \\
\hline 71 & EXFO Inc. & 1 \\
\hline 72 & Fennec Pharmaceuticals Inc. & 2 \\
\hline 73 & Finning International Inc. & 3 \\
\hline 74 & Firan Technology Group Corporation & 4 \\
\hline 75 & First Quantum Minerals Ltd. & 5 \\
\hline 76 & Fortis Inc. & 1 \\
\hline 77 & Gabriel Resources Ltd. & 2 \\
\hline
\end{tabular}




\begin{tabular}{|l|l|l|}
\hline S. No. & Company Name & Group \\
\hline 78 & Gildan Activewear Inc. & 3 \\
\hline 79 & Goldcorp Inc. & 4 \\
\hline 80 & Golden Queen Mining Co. Ltd. & 5 \\
\hline 81 & Golden Star Resources Ltd. & 1 \\
\hline 82 & Goodfellow Inc. & 2 \\
\hline 83 & Hammond Manufacturing Company Limited & 3 \\
\hline 84 & Helix BioPharma Corp. & 4 \\
\hline 85 & High Liner Foods Incorporated & 5 \\
\hline 86 & Husky Energy Inc. & 1 \\
\hline 87 & Hydrogenics Corporation & 2 \\
\hline 88 & IAMGold Corporation & 3 \\
\hline 89 & Imperial Metals Corporation & 4 \\
\hline 90 & Imperial Oil Limited & 5 \\
\hline 91 & Inter Pipeline Ltd. & 1 \\
\hline 92 & Interfor Corporation & 2 \\
\hline 93 & Intertape Polymer Group Inc. & 3 \\
\hline 94 & Intrinsyc Technologies Corporation & 4 \\
\hline 95 & Jean Coutu Group (PJC) Inc. (The) & 5 \\
\hline 96 & Kinross Gold Corporation & 1 \\
\hline 97 & Lassonde Industries Inc. & 2 \\
\hline 98 & Leon's Furniture Limited & 3 \\
\hline 99 & Linamar Corporation & 4 \\
\hline 100 & Loblaw Companies Limited & 5 \\
\hline 101 & Logistec Corporation & 1 \\
\hline 102 & MacDonald, Dettwiler and Associates Ltd. & 2 \\
\hline 103 & Magellan Aerospace Corporation & 3 \\
\hline 104 & Magna International Inc. & 4 \\
\hline 105 & Maple Leaf Foods Inc. & 5 \\
\hline 106 & Marsulex Inc/Chemtrade Logistics Inc & 1 \\
\hline 107 & Martinrea International Inc. & 2 \\
\hline 108 & McEwen Mining Inc. & 3 \\
\hline 109 & MDC Partners Inc. & 4 \\
\hline 110 & Methanex Corporation & 5 \\
\hline 111 & Metro Inc. & 1 \\
\hline 112 & Microbix Biosystems Inc. & 2 \\
\hline 113 & Mountain Province Diamonds Inc. & 3 \\
\hline 114 & Mullen Group Ltd. & 4 \\
\hline 115 & Nevsun Resources Ltd. & \\
\hline 116 & Newalta Corporation & \\
\hline & & \\
\hline
\end{tabular}




\begin{tabular}{|l|l|l|}
\hline S. No. & Company Name & Group \\
\hline 117 & Newfoundland Capital Corporation Limited & 2 \\
\hline 118 & NGEx Resources Inc. & 3 \\
\hline 119 & Norbord Inc. & 4 \\
\hline 120 & Norsat International Inc. & 5 \\
\hline 121 & North American Palladium Ltd. & 1 \\
\hline 122 & North West Company Inc. & 2 \\
\hline 123 & Northland Power Inc. & 3 \\
\hline 124 & Novagold Resources Inc. & 4 \\
\hline 125 & Novelion Therapeutics Inc. & 5 \\
\hline 126 & Nuvo Pharmaceuticals Inc. & 1 \\
\hline 127 & NXT Energy Solutions Inc. & 2 \\
\hline 128 & Obsidian Energy Ltd. & 3 \\
\hline 129 & Oncolytics Biotech Inc. & 4 \\
\hline 130 & Open Text Corporation & 5 \\
\hline 131 & Orvana Minerals Corp. & 1 \\
\hline 132 & Pacific Insight Electronics Corp. & 2 \\
\hline 133 & Pan American Silver Corp. & 3 \\
\hline 134 & Paramount Resources Ltd. & 4 \\
\hline 135 & Parkland Fuel Corporation & 5 \\
\hline 136 & Pason Systems Inc. & 1 \\
\hline 137 & Pembina Pipeline Corporation & 2 \\
\hline 138 & Pengrowth Energy Corporation & 3 \\
\hline 139 & Peyto Exploration \& Development Corp. & 4 \\
\hline 140 & Potash Corporation of Saskatchewan Inc. & 5 \\
\hline 141 & Precision Drilling Corporation & 1 \\
\hline 142 & Premium Brands Holdings Corporation & 2 \\
\hline 143 & ProMetic Life Sciences Inc. & 3 \\
\hline 144 & Pulse Seismic Inc. & 4 \\
\hline 145 & Quebecor Inc. & 5 \\
\hline 146 & Reitmans (Canada) Limited & 1 \\
\hline 147 & Richelieu Hardware Ltd. & 2 \\
\hline 148 & Richmont Mines Inc. & 3 \\
\hline 149 & Ritchie Bros. Auctioneers Incorporated & 4 \\
\hline 150 & RMP Energy Inc. & 5 \\
\hline 151 & Rogers Communications Inc. & 1 \\
\hline 152 & Rogers Sugar Inc. & 2 \\
\hline 153 & Russel Metals Inc. & 3 \\
\hline 154 & Saputo Inc. & \\
\hline 155 & Shaw Communications Inc. & \\
\hline & & \\
\hline
\end{tabular}




\begin{tabular}{|l|l|l|}
\hline S. No. & Company Name & Group \\
\hline 156 & ShawCor Ltd. & 1 \\
\hline 157 & Sherritt International Corporation & 2 \\
\hline 158 & Silver Standard Resources Inc. & 3 \\
\hline 159 & SNC-Lavalin Group Inc. & 4 \\
\hline 160 & Spectral Medical Inc. & 5 \\
\hline 161 & Stantec Inc. & 1 \\
\hline 162 & Strongco Corporation & 2 \\
\hline 163 & Stuart Olson Inc. & 3 \\
\hline 164 & Suncor Energy Inc. & 4 \\
\hline 165 & SunOpta Inc. & 5 \\
\hline 166 & Tanzanian Royalty Exploration Corporation & 1 \\
\hline 167 & Taseko Mines Limited & 2 \\
\hline 168 & Teck Resources Limited & 3 \\
\hline 169 & Telesta Therapeutics Inc. & 4 \\
\hline 170 & TELUS Corporation & 5 \\
\hline 171 & Tembec Inc. & 1 \\
\hline 172 & Tesco Corp. & 2 \\
\hline 173 & Theratechnologies Inc. & 3 \\
\hline 174 & Thomson Reuters Corporation & 4 \\
\hline 175 & Toromont Industries Ltd. & 5 \\
\hline 176 & Torstar Corporation & 1 \\
\hline 177 & Total Energy Services Inc. & 2 \\
\hline 178 & Touchstone Exploration Inc. & 3 \\
\hline 179 & TransAlta Corporation & 4 \\
\hline 180 & Transat A.T. Inc. & 5 \\
\hline 181 & TransCanada Corporation & 1 \\
\hline 182 & Transcontinental Inc. & 2 \\
\hline 183 & TransGlobe Energy Corporation & 3 \\
\hline 184 & Trican Well Service Ltd. & 4 \\
\hline 185 & Trinidad Drilling Ltd. & 5 \\
\hline 186 & Turbo Power Systems Inc. & 1 \\
\hline 187 & Turquoise Hill Resources Ltd. & 2 \\
\hline 188 & TVA Group Inc. & 3 \\
\hline 189 & TWC Enterprises Limited & 4 \\
\hline 190 & Uni-Select Inc. & 5 \\
\hline 191 & Uranium One Inc. & 1 \\
\hline 192 & Valeant Pharmaceuticals International Inc. & 2 \\
\hline 193 & Valener Inc. & \\
\hline 194 & Velan Inc. & 3 \\
\hline & & \\
\hline
\end{tabular}




\begin{tabular}{|l|l|l|}
\hline S. No. & Company Name & Group \\
\hline 195 & Veresen Inc. & 5 \\
\hline 196 & Vermilion Energy Inc. & 1 \\
\hline 197 & Vista Gold Corp. & 2 \\
\hline 198 & Wajax Corporation & 3 \\
\hline 199 & Waste Connections, Inc. & 4 \\
\hline 200 & West Fraser Timber Co. Ltd. & 5 \\
\hline 201 & Western Forest Products Inc. & 1 \\
\hline 202 & WestJet Airlines Ltd. & 2 \\
\hline 203 & Weston (George) Limited & 3 \\
\hline 204 & Westport Fuel Systems Inc. & 4 \\
\hline 205 & Winpak Ltd. & 5 \\
\hline 206 & Yorbeau Resources Inc. & 1 \\
\hline 207 & Zargon Oil \& Gas Ltd. & 2 \\
\hline 208 & ZCL Composites Inc. & 3 \\
\hline
\end{tabular}




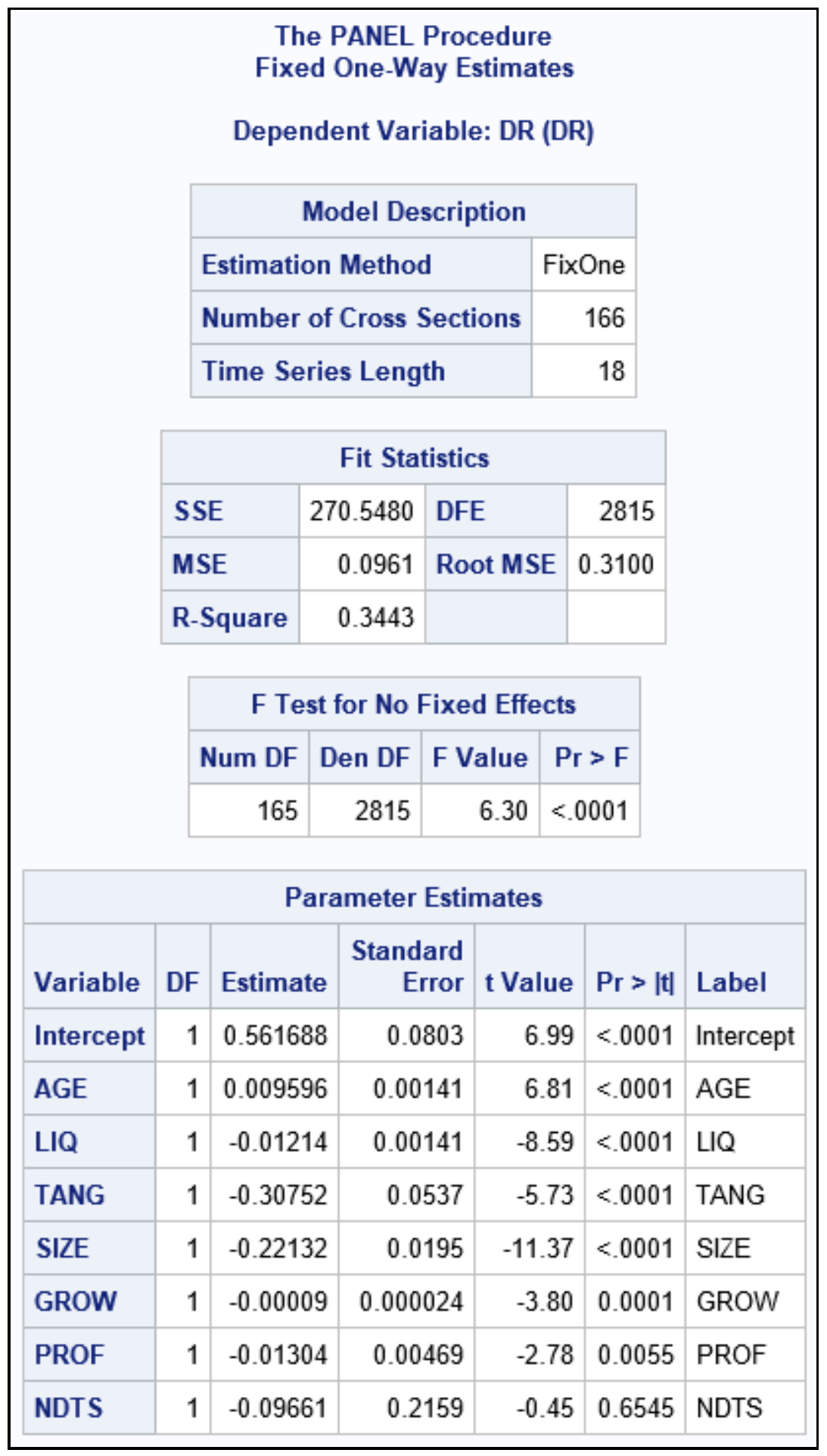

Figure 20: Robustness test results after excluding Group 2 companies - one-way fixed effects model for 1999 to 2016 


\section{REFERENCES}

Aivazian, V. A., Ge, Y., \& Qiu, J. (2003). The impact of leverage on firm investment: Canadian evidence. Journal of Corporate Finance, 11(1-2), 277-291.

Akkranupornpong, J., \& Kleiner, B. H. (2004). When to issue the company stock. Management Research News, 27(4/5), 82-90.

Alipour, M., Mohammadi, M. farhad S., \& Derakhshan, H. (2015). Determinants of capital structure: an empirical study of firms in Iran. International Journal of Law and Management, 57(1), 53-58.

Ardalan, K. (2003). Theories and controversies in finance : a paradigmatic overview. International Journal of Social Economics, 30(1/2), 199-209.

Baker, M., \& Wurgler, J. (2002). Market Timing and Capital Structure. The Journal of Finance, $57(1), 1-32$.

Baltagi, B. H. (2005). Econometric Analysis of Panel Data (3rd Edition). John Wiley \& Sons Inc., New York.

Becker, B., Allen, B., Ayotte, K., Baird, D., Baldwin, C., Bouvard, M., ... Lemmon, M. (2011). Fiduciary Duties and Equity-Debtholder Conflicts.

Bharath, S. T., Pasquariello, P., \& Wu, G. (2009). Does asymmetric information drive capital structure decisions. Review of Financial Studies, 22(8), 3211-3243.

Booth, L., Aivazian, V., Demirguc-Kunt, A., \& Maksimovic, V. (2001). Capital Structures in Developing Countries. The Journal of Finance, 56(1), 87-130.

Bowring, M. A. (2000). De/Constructing Theory: A Look at the Institutional Theory that Positivism Built. Journal of Management Inquiry, 9(3), 258-270.

Bradley, M., Jarrell, G. A., \& Kim, E. H. (1984). On the Existence of an Optimal Capital 
Structure: Theory and Evidence. The Journal of Finance, 39(3), 857-878.

Buferna, F., Bangassa, K., \& Hodgkinson, L. (2005). Determinants of Capital Structure Evidence from Libya. Research Paper Series.

Chadha, S., \& Sharma, A. (2015). Determinants of capital structure: an empirical evaluation from India. Journal of Advances in Management Research, 12(1), 3-14.

Chen, J., \& Strange, R. (2005). The determinants of capital structure: Evidence from Chinese listed companies. Economic Change and Restructuring, 38(1), 11-35.

Cloyd, C. B., Limberg, S. T., \& Robinson, J. R. (1997). The impact of federal taxes on the use of debt by closely held corporations. National Tax Journal, 50(2), 261-277.

Danso, A., \& Adomako, S. (2010). The financing behaviour of firms and financial crisis. Managerial Finance International Journal of Islamic and Middle Eastern Finance and Management Journal of Economic Studies, 40(1), 1159-1174.

Davis, A. H. R. (1987). Effective Tax Rates as Determinants of Canadian Capital Structure. Financial Management, 16(3), 22.

De Wet, J. (2006). Determining the optimal capital structure: a practical contemporary approach. Meditari Accountancy Research, 14(2), 1-16.

DeAngelo, H., \& Masulis, R. W. (1980). Optimal capital structure under corporate and personal taxation. Journal of Financial Economics, 8(1), 3-29.

Donaldson, G. (1961). Corporate debt capacity; a study of corporate debt policy and the determination of corporate debt capacity. Boston: Division of Research, Graduate School of Business Administration, Harvard University.

Dybvig, P. H., \& Wang, Y. (2002). Debt and Equity. Journal of Finance, 39(18), 36-56.

Fama, E. F., \& French, K. R. (2002). Testing trade-off and pecking order predictions about 
dividends and debt. The Review of Financial Studies, 15(August 1999), 1-33.

Fluck, Z. (1998). Optimal Financial Contracting: Debt versus Outside Equity. The Review of Financial Studies, 11(2), 383-418.

Frank, M. Z., \& Goyal, V. K. (2003). Testing the pecking order theory of capital structure. Journal of Financial Economics (Vol. 67).

Gaud, P., Jani, E., Hoesli, M., \& Bender, A. (2005). The Capital Structure of Swiss Companies: an Empirical Analysis Using Dynamic Panel Data. European Financial Management, $11(1), 51-69$.

Gill, A., \& Mathur, N. (2011). Factors that Influence Financial Leverage of Canadian Firms. Journal of Applied Finance and Banking, 1(2), 19-37.

Hackbarth, D. (2008). Managerial Traits and Capital Structure Decisions. Journal of Financial and Quantitative Analysis, 43(04), 843-881.

Harris, M., \& Raviv, A. (1991). The Theory of Capital Structure. The Journal of Finance, 46(1), $297-355$.

Hossain, A., \& Nguyen, D. (2016a). Capital Structure, Firm Performance and the Recent Financial Crisis. Journal of Accounting and Finance, 16(1), 76.

Hossain, A., \& Nguyen, D. (2016b). Did Canada Survive the Financial Crisis Better than the United States? Journal of Applied Business and Economics, 18(2), 11-21.

Hsiao, C. (2003). Analysis of panel data. Cambridge University Press.

Jensen, M. C. (1986). Agency Cost Of Free Cash Flow, Corporate Finance, and Takeovers. American Economic Review, 76(2), 323-329.

Jensen, M., \& Meckling, W. (1976). Theory of the Firm: Managerial Behavior, Agency Costs and Ownership Structure. Journal of Financial Economics, 3(4), 305-360. 
Kraus, A., \& Litzenberger, R. H. (1973). A State-Preference Model of Optimal Financial Leverage. The Journal of Finance, 28(4), 911-922.

López-Gracia, J., \& Sogorb-Mira, F. (2008). Testing trade-off and pecking order theories financing SMEs. Small Business Economics, 31(2), 117-136.

Matemilola, B. T., Bany-Ariffin, A. N., \& McGowan Jr., C. B. (2012). Trade Off Theory Against Pecking Order Theory of Capital Structure in a Nested Model: Panel Gmm Evidence from South Africa, 9(2), 133-147.

Michaelas, N., Chittenden, F., \& Poutziouris, P. (1999). Financial policy and capital structure choice in UK SMEs: evidence from company panel data. Small Business Economics, 12(2), 113-130.

Miller, M. H. (1977). Debt and taxes. The Journal of Finance, 32(2), 261-275.

Mittoo, U. R., \& Zhang, Z. (2008). The capital structure of multinational corporations: Canadian versus U.S. evidence. Journal of Corporate Finance, 14(5), 706-720.

Mittoo, U. R., \& Zhang, Z. (2010). Bond Market Access, Credit Quality, and Capital Structure: Canadian Evidence. Financial Review, 45(3), 579-602.

Modigliani, F., \& Miller, M. H. (1958). The cost of capital, corporation finance and the theory of investment. Revista de Administração e Contabilidade Da Unisinos, 5(2), 154-155.

Modigliani, F., \& Miller, M. H. (1963). Corporate income taxes and the cost of capital: a correction. The American Economic Review, 53(3), 433-443.

Mukherjee, S., \& Mahakud, J. (2012). Are Trade-off and Pecking Order Theories of Capital Structure Mutually Exclusive? Evidence from Indian Manufacturing Companies. Journal of Management Research, 12(1), 41-55.

Myers, S. C. (1977). Determinants of corporate borrowing. Journal of Financial Economics, 
$5(2), 147-175$.

Myers, S. C. (2001). Capital Structure. The Journal of Economic Perspectives, 15(2), 41-46.

Myers, S. C., \& Majluf, N. S. (1984). Corporate financing and investment decisions when firms have information that investors do not have. Journal of Financial Economics, 13(2), 187221.

Nunkoo, P. K., \& Boateng, A. (2010). The empirical determinants of target capital structure and adjustment to long-run target: Evidence from Canadian firms. Applied Economics Letters, 17(10), 983-990.

Rajan, R. G., \& Zingales, L. (1995). What do we know about Capital Structure? Some evidence from International Data. The Journal of Finance, 50(5), 1421-1460.

Rakhmayil, S., \& Yuce, A. (2008). Do CEO Qualifications Affect Capital Structure? Journal of Applied Business and Economics, 9(2), 76-85.

Rakhmayil, S., \& Yuce, A. (2012). NAFTA Effect On Company Values And Performance. International Business \& Economics Research Journal, 11(4), 407-420.

Ross, S., Westerfield, R., Jordan, B., \& Roberts, G. (2016). Fundamentals of corporate finance (Ninth Edition). Canada: McGrawll Hill Education.

Sayılgan, G., Karabacak, H., \& Küçükkocaolu, G. (2006). The Firm-Specific Determinants of Corporate Capital Structure: Evidence from Turkish Panel Data. Investment Management and Financial Innovations, 3(3), 125-139.

Sbeiti, W. (2010). The Determinants of Capital Structure: Evidence from the GCC Countries. International Research Journal of Finance and Economics, 47, 54-79.

Sheikh, N. A., \& Wang, Z. (2011). Determinants of capital structure An empirical study of firms in manufacturing industry of Pakistan. Review of Financial Economics, 1(2), 40-52. 
Shyam-Sunder, L., \& Myers, S. C. (1999). Testing static tradeoff against pecking order models of capital structure. Journal of Financial Economics, 51(2), 219-244.

Smyth, D. J., \& Hsing, Y. (1995). In Search of an Optimal Debt Ratio for Economic Growth. Contemporary Economic Policy, 13(4), 51-59.

Stretcher, R., \& Johnson, S. (2011). Capital structure: professional management guidance. Managerial Finance, 37(8), 788-804.

Titman, S., \& Wessels, R. (1988). The Determinants of Capital Structure Choice. The Journal of Finance, 43(1), 1-19.

Toy, N., Stonehill, A., Remmers, L., Wright, R., \& Beekhuisen, T. (1974). A Comparative International Study of Growth, Profitability, and Risk as Determinants of Corporate Debt Ratios in the Manufacturing Sector. The Journal of Financial and Quantitative Analysis, $9(5), 875-886$.

Verweij, A. C., Sijtsma, K., \& Koops, W. (1999). An Ordinal Scale for Transitive Reasoning by Means of a Deductive Strategy. International Journal of Behavioral Development, 23(1), $241-264$.

Viviani, J. L. (2008). Capital structure determinants: An empirical study of French companies in the wine industry. International Journal of Wine Business Research, 20(2), 171-194.

Wiwattanakantang, Y. (1999). An empirical study on the determinants of the capital structure of Thai firms. Pacific Basin Finance Journal, 7(3-4), 371-403. 